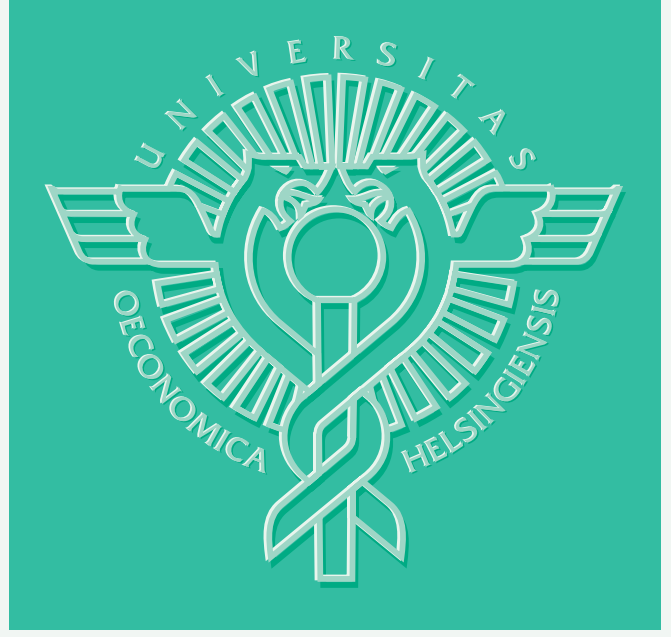

Elias Rantapuska

\title{
EX-DIVIDEND DAY TRADING: WHO, HOW, AND WHY?
}




\title{
Elias Rantapuska
}

\section{EX-DIVIDEND DAY TRADING: WHO, HOW, AND WHY?}

\author{
Finance \\ November \\ 2005
}


HELSINGIN KAUPPAKORKEAKOULU

HELSINKI SCHOOL OF ECONOMICS

PL 1210

FIN-00101 HELSINKI

FINLAND

(C) Elias Rantapuska and

Helsinki School of Economics

ISSN 1235-5674

ISBN 951-791-978-6 (Electronic working paper)

Helsinki School of Economics -

HSE Print 2005 


\title{
Ex-dividend day trading: who, how, and why?
}

\author{
Elias Rantapuska* \\ Helsinki School of Economics and GSF
}

First draft: June 18, 2004

This version: November 30, 2005

\begin{abstract}
This study examines ex-dividend day trading behavior of all investors in the entire Finnish stock market. Consistent with the dynamic dividend clientele explanation, investors with a preference for dividend income buy shares cum-dividend and sell ex-dividend; the reverse is true for investors with the opposite preferences. Untaxed mutual funds engage in overnight arbitrage by selling shares cum and buying ex. Studying trades at the level of an individual investor shows idiosyncratic risk to be an important determinant in the choice of tax arbitrage stock. Analysis of the proportion of tax-motivated overnight trades reveals that transaction costs and dividend yield jointly determine whether the degree of tax arbitrage activity is nonzero.
\end{abstract}

\section{JEL classification: G35}

Keywords: ex-dividend day, tax arbitrage, dividend clientele

\footnotetext{
* Correspondence: Elias Rantapuska, Helsinki School of Economics, Department of Accounting and Finance, P.O. BOX 1210, Finland. Tel: +358-9-43138974, Fax: +358-9-43138678, Email: elias.rantapuska@hse.fi. I would like to thank Matti Keloharju and Samuli Knüpfer for insightful discussions and Juhani Linnainmaa for help in computing capital gains. Seminar and workshop participants at Helsinki School of Economics, Finnish Doctoral Programme in Economics, FMA European Conference 2005, Sean Cleary, Markku Kaustia, Juha-Pekka Kallunki, Matti Kukkonen, Vesa Puttonen, and Kristian Rydqvist provided valuable comments and suggestions. In addition, financial support from Okobank Group Research Foundation, the Finnish Foundation for Advancement of Securities Markets, Yrjö Uitto Foundation, Helsinki School of Economics Foundation, Wihuri Foundation, and the Academy of Finland is gratefully acknowledged.
} 


\section{Introduction}

Very few overnight share price changes convey as much fundamental information as stock returns on the ex-dividend day. Elton and Gruber (1970) introduced the idea that ex-day returns can be used to test if personal taxes affect security prices and to deduce the identity of the marginal investor. In more than three decades, hundreds of studies have examined the ex-day price behavior of stocks to find out the identity of the marginal investor. There is a consensus that taxes affect security prices, but the identity of marginal investor and the degree of impact on prices is still debatable.

An ideal starting point for an analysis on the identity of the marginal investor is to study which investors trade around the ex-dividend day. However, until very recently, researchers have not had access to individual investor level data and have used various techniques to infer the identity of the marginal investor from price and volume data. The problem is that it is impossible to disentangle total trading volume to delineate trades by every single investor. Thus, information on the marginal investor comes largely from studies examining share price changes and the aggregate trading volume on the ex-dividend day.

There are two competing hypotheses as to the identity of investors trading around the exdividend day. According to the tax hypothesis of Elton and Gruber (1970), long-term pricesetting investors time their trades around the ex-dividend day. The short-term trading hypothesis of Kalay (1982) argues that arbitrageurs with equal preference for dividend income and capital gains trade around the ex-day, a sufficient condition to guarantee a price drop exactly the amount of dividend, plus or minus the roundtrip transaction costs. Researchers have used indirect methods to differentiate these two hypotheses often linking the extent of the price drop or trading volume to firm-specific variables. It is unlikely that on any given day the market would be populated only by long- or short-term traders. Instead, the total trading volume is likely to be driven by both long- and short-term trading clienteles. Hence, any inference made from the extent of a price drop on the ex-day is complicated by the fact that both long- and short-term traders may be trading actively.

To overcome the obvious shortfall of studying only price and volume data, my research takes a direct look at trades that take place around the ex-dividend day. High-quality data consisting of the trading records of all market participants allow a close examination of investor behavior around the ex-dividend day in virtually every listed stock. Access to not only the identity of traders in the entire market but also to detailed investor level data such as capital 
gains, portfolio values, and portfolio composition facilitates a direct test of whether investors actually behave as described by the ex-dividend day theories.

By using the comprehensive investor level data from an entire stock market to study the trades around the ex-day, I make two contributions to the literature. First, I document who trades, how much, and in which direction around the ex-dividend day. The results strongly suggest that tax status drives investors to change the direction of their trades around the ex-dividend day. Households and corporate traders who have a preference for dividend income in the Finnish tax environment, switch from buys to sells after the ex-day. Correspondingly, foreigners who are taxed more heavily on dividend income, switch from sells to buys on the ex-dividend day. Second, I provide empirical evidence on the determinants of short-term trading around the exdividend day by domestic household and nonfinancial corporate investors. These investors are found to engage in tax arbitrage in stocks with a high dividend yield, low transaction costs, low beta, low idiosyncratic risk, and in which they have small positions or no position previously. The results show that mutual funds also engage in short-term arbitrage trading, but their profits before transaction costs are modest. On average, a mutual fund earned an overnight return of $0.33 \%$ before transaction costs for a roundtrip arbitrage trade.

The remainder of the paper is organized as follows. The next section reviews literature on dynamic dividend clienteles. Section 3 explains the relevant features of capital income taxation in Finland and how this affects the research design. Section 4 describes the data. Section 5 investigates the size of the ex-dividend day price drop, the magnitude of trading by investor category, the determinants of trading activity, and the degree of tax arbitrage activity as a fraction of total trading volume. Finally, Section 6 concludes and suggests avenues for further research.

\section{Dynamic dividend clienteles}

The history of ex-dividend studies dates back to Elton and Gruber (1970), who argue that the tax bracket of the marginal investor can be inferred from share price change divided by the value of cash-dividend on the ex-day. This insight, often referred to as the tax hypothesis, rests on the argument that marginal stockholders will be indifferent between selling shares cum- and exdividend, and thus the price drop must in equilibrium reflect the relative dividend and capital income tax rates of the marginal investor.

Kalay (1982) argues against the tax hypothesis by suggesting that trades by arbitrageurs, not by tax clienteles, drive stock prices on the ex-dividend day. This model is based on the argument that risk-neutral investors who are indifferent between an equal amount of pretax capital gains 
and dividend income could realize arbitrage profits by short-term trading if the price drop on the ex-dividend day is different from the value of dividend. Hence, any deviation from the value of the dividend must be due to market frictions causing limits to arbitrage.

For a moment, assume that either the tax hypothesis of Elton and Gruber (1970) or the shortterm trading hypothesis of Kalay (1982) holds, and one group of marginal investors drive security prices on the ex-dividend day. Now, unless every agent in the economy has the same tax rate on dividend income and capital appreciation, investors can realize mutual gains at the expense of the government by trading with each other around the first ex-dividend day. Hence, investors valuing dividends most relative to capital gains should hold and buy stocks cum-dividend, and investors who would be disadvantaged to receive dividends should be on the sell-side. Then, these trades should be reversed on the first ex-day. This is the key argument of dynamic dividend clientele models (Michaely and Vila 1995, 1996; Michaely, Vila, and Wang, 1996; Dhaliwal and Li, 2005), which are developed based on the argument that taxes affect trading decisions, as well as prices. Heterogeneity of agents trading around the ex-day is a central building block of the dynamic models for ex-day trading; the ex-day is not driven by any single group of investors, but by the interplay of trading decisions by investors with different tax statuses.

Some authors propose that not only taxes but also risk drives trading decisions around the ex-dividend day. Michaely and Vila $(1995,1996)$ argue that ex-dividend day traders expose themselves to a substantial risk that must be accounted for by incorporating risk aversion in a model of ex-day trading behavior. In reality, no investor would be willing to take an unlimited position in a stock even if the expected gain is positive, which is what should happen in case of a true arbitrage opportunity. Due to idiosyncratic risk, an investor engaging in tax arbitrage will trade only as long as the advantage from the expected short-term gain exceeds the disadvantage of being too heavily invested in the traded stock. This argument is consistent with Heath and Jarrow (1988), who show that an investor cannot make riskless profits simply because of the variation in ex-dividend day price drop. Similar argument on idiosyncratic risk is also in the model of Michaely, Vila, and Wang (1996), which also incorporates transaction cots.

Authors of a distinct branch of literature argue that differentiating between the tax hypothesis and the short-term trading hypothesis is further complicated by market microstructure considerations. Empirical evidence in Eades, Hess and Kim (1984), Bali and Hite (1998), and Frank and Jagannathan (1998) suggests that transaction costs as well as price discreteness explain why share prices do not drop on average by the amount of the dividend on the ex-dividend day. However, most other scholars share the view that the microstructure explanations are not 
sufficient to fully explain the variation in ex-dividend day ratios (Graham, 2003; Graham, Michaely, and Roberts, 2003; Allen and Michaely, 2004).

Empirical work trying to differentiate the tax hypothesis and the short-term trading hypothesis on the identity of the marginal investor by using price and volume data is voluminous, and includes contributions by Lakonishok and Vermaelen (1986), Karpoff and Walkling (1988), Kato and Loewenstein (1995), Lasfer (1995), Green and Rydqvist (1999), Naranjo, Nimalendran, and Ryngaert (2000), and Callaghan and Barry (2003), to name a few.

More recent research has been able to directly observe ex-dividend day trading volume by investor category. Koski and Scruggs (1998) examine NYSE audit file data and find evidence consistent with the idea that differences in tax rates cause investors to trade around the ex-day. Felixson and Liljeblom (2004) also provide direct evidence on trading around the ex-day by investor tax category. Furthermore, Graham and Kumar (2005) investigate the trades of individual investors at a large discount brokerage house and find evidence on taxes driving trading decisions.

So far, the ex-dividend day literature is missing a detailed examination of the investor and stock characteristics that drive tax- and arbitrage-motivated trades. This study bridges the gap by performing a throughout analysis on the level of the market, the firm, and the investor with data on all trades by every investor in an entire stock market.

\section{Capital income taxation in Finland}

By international standards, capital income taxation was relatively straightforward in Finland during the sample period of 1995-2002. In particular, two major characteristics in the capital income tax laws substantially simplify research design. First, there are no differences in capital income tax rates of domestic investors within an investor category. That is, once the legal status of an investor is identified, I also know whether the investor is taxed at all, and what is the applicable nominal tax rate (if any) on capital gains and dividends. Second, the dividend and capital income tax rate is independent from the holding period of a security.

\subsection{Dual income tax system}

During the sample period, Finland had a dual income tax. That is, labor income and capital gains were taxed separately for all sources of income. The only exception is capital income from private companies. However, for publicly listed corporations income tax duality always applies 
and thus the amount of labor income, which is unobservable in this study, has no effect on the marginal tax rate of capital income. Hence, the propensity of an investor to engage in ex-dividend day trading is not driven by differences in labor income.

\subsection{Statutory tax-rates and dividend imputation system}

All investors except for nonprofit institutions and mutual funds are subject to capital income and dividend taxes at the investor level. The statutory rate for capital income equaled the statutory rate for dividend income during the sample period, although the tax rate changed twice. Until the end of 1995, the tax rate was $25 \%$, and was raised to $28 \%$ at the beginning of 1996 . Subsequently, the tax rate was raised to $29 \%$ at the beginning of year 1999 . Corporate profits and dividends are both taxed at the firm level at a flat rate. Dividends are fully imputed via a tax credit system that guarantees an effective dividend tax rate of zero for domestic investors. ${ }^{1}$ For example, consider a domestic investor who receives EUR 1000 dividend income in a fiscal year. In the tax form, the domestic investor declares EUR 1000 dividend income, EUR 290 dividend tax, and EUR 290 imputed dividend tax credit. The EUR 290 dividend tax and the EUR 290 tax credit are netted out, and subsequently the domestic taxable investor does not have to pay any tax on the dividend income of EUR 1000. In essence, the full imputation system is a smokescreen designed to escape the criticism that dividends are not taxed at the investor level.

The imputation system does not generally apply to foreigners, who may have to pay an additional withholding tax of up to $29 \%$, depending on the tax treaty between Finland and the country of residence of the foreign investor. For investors resident in the United States and the United Kingdom, the withholding tax is $15 \%$. Institutions such as mutual funds and nonprofit foundations do not receive the imputation tax credit as they do not pay taxes. Finland's imputation system of dividends is similar to the system in France, Germany, Italy, and Spain, but less complicated.

\subsection{Taxation of short-term trading profits}

Finnish tax law does not differentiate between long- and short-term capital gains. Capital gain for a share held overnight is taxed at exactly the same rate as for a share held for five years. Furthermore, the tax law does not explicitly ban the dynamic tax avoidance strategy where an

\footnotetext{
${ }^{1}$ There are two minor exceptions. In 1996 and 2000 capital income tax rates were raised, but dividends were imputed at the previous year's tax rate. The effective tax rate on dividends was $4.0 \%$ in 1996 and $1.4 \%$ in 2000 .
} 
investor creates artificial losses by buying shares cum-dividend and selling the shares exdividend. Thus, there are no explicit legal restrictions for tax avoidance by ex-dividend day trading such as the holding period requirements for qualified dividends in the US. Although the tax authorities can levy a tax on any transaction deemed to have a tax avoidance rather than economic purpose, they did not exercise this option during the sample period. ${ }^{2}$

\subsection{Taxation of capital gains and dividends}

Capital gains are taxed on realization at a flat rate, which was equal to the corporate tax rate during the sample period. An investor realizing capital gains has the option to calculate the gain on $20 \%$ of the sale price instead of the purchase price. ${ }^{3}$ Thus, realized capital gains can be calculated using the formula Min (sale price - purchase price, sale price x $80 \%$ ). The same capital gains formula applies to all domestic investors subject to taxes. Realized capital losses can be deducted from realized capital gains in taxation up to any limit, and carried forward for up to three years. For these reasons, the ex post realized capital gains tax rate can differ from the nominal tax rate. Kukkonen (2000, p. 150) estimates an effective capital gains tax rate of $15 \%$ in 1995 for a sample of wealthy individuals living in Helsinki.

Because of the full imputation system and effective zero tax rate on dividend income, Finnish domestic investors prefer dividends to capital gains. More precisely, EUR 1.00 in dividend income yields the same after-tax cash flow as EUR $1.00-1.41$ in pretax capital appreciation. ${ }^{4}$ Because of the tax deductibility of capital losses, an investor with strictly positive capital gains values dividends closer to EUR 1.41 than EUR 1.00. Correspondingly, an investor with large capital losses would be indifferent between EUR 1 in dividend income and EUR 1 in capital gains. This is because a taxable investor with large capital losses for the fiscal year does not benefit from realizing a loss from ex-day trading, whereas an investor with large capital gains does. For a domestic investor with strictly positive capital gains, tax arbitrage is possible unless the price decline is more than 1.41 times the dividend paid. For a more detailed discussion of the

\footnotetext{
${ }^{2}$ The Supreme Administrative Court of Finland resolved a precedent case in 2004 (KHO:2004:8, 2725/2/02) for the deductibility of capital losses in an intraday transaction, where the same shares were sold to and bought from the same broker during the same trading day. The court deemed that no capital loss deduction could be made for shares bought back within the same day. This decision was handed down 15 months after the end of the sample period and did not concern a transaction in which shares were held overnight. Hence, it is unlikely the investors considered short-term ex-dividend day trading to have potential legal implications.

${ }^{3}$ Prior to fiscal year 1999, the alternative capital gains tax basis was $30 \%$ of the sale price.

${ }^{4}$ The Finnish capital gains tax rate changed twice during the sample period. From 1993 to 1995, the tax-rate was 25\% effectively imposing a $1 /(1-0.25)=1.33$ upper limit to the dividend preference ratio. The capital gains tax rate in 1996-1999 was $28 \%$ and $29 \%$ in $2000-2002$. This yields a maximum dividend preference ratio of 1.39 and 1.41 , respectively.
} 
boundaries of ex-dividend day tax arbitrage in a country with a dividend imputation system, see MacDonald (2001) for a German example and Liljeblom, Löflund, and Hedvall (2001) for a Finnish one.

Table 1 illustrates how a domestic investor can engage in tax arbitrage around the exdividend day. To avoid confusion, I will use the word "arbitrageur" throughout this study to refer to nontaxable short-term investors and "tax arbitrageur" to refer to domestic taxable short-term investors.

Table 1

Illustration of tax arbitrage by domestic taxable investors

This table illustrates how a domestic taxable investor is able to profit from trading around the ex-dividend day under two scenarios. The example is based on Finnish tax laws effective in 2001-2002 when the capital gains and dividend tax rate were $29 \%$ and the dividend tax credit was fully imputed. This yields a dividend preference ratio of 1.41 to domestic taxable investors with realized capital gains.

Price drop equals dividend

Realized capital gains

Tax due on capital gains

Buy 50 shares at EUR 10 paying EUR 2 dividend

Dividend

Sell shares ex-dividend

Net cash outflow

Deduction from tax-bill

Net tax arbitrage profit
Price drop equals 1.41 times the dividend

141 Realized capital gains

Buy 50 shares at EUR 10 paying EUR 2 dividend

$-500-500$

100 Dividend 100

400 Sell shares ex-dividend

359

Net cash outflow

$0.29 \times 100=29$ Deduction to tax-bill

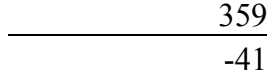

29 Net tax arbitrage profit
$0.29 \times 141=41$

0

\subsection{Summary and implications of capital income taxation by investor category}

The implications for the ex-dividend day trading incentives for each investor category are as follows:

- Nontaxable domestic investors, such as nonprofit institutions, government entities, and pension and mutual funds have equal preferences for EUR 1 of dividend income and EUR 1 in capital gains. They have an incentive to engage in short-term trading as long as the price drop on the ex-dividend day does not equal 1.

- All other domestic investors in Finland have identical nominal tax rates on capital income. With the imputation system, the effective tax rate for dividends is zero and for capital gains between $25 \%$ and $29 \%$. Domestic households, nonfinancial corporations, and financial corporations have a preference for dividend income. At most, EUR 1 in dividend income is equally preferred to EUR 1.41 in capital gains. Domestic taxable investors with capital gains 
to be sheltered have an incentive to buy shares cum-dividend and sell ex-dividend, unless the price decline is greater than 1.41 times the dividend paid.

- Most foreign investors do not receive the imputation tax credit and are subject to an additional withholding tax. For a foreign investor, EUR 1 in capital gains is, in most cases, preferred to EUR 1 in dividend income. The majority of foreign investors thus have an incentive to sell shares cum-dividend and buy ex-dividend, unless the expected price decline on the ex-dividend day is significantly less than 1 .

\section{Data}

The bulk of the data come from the Finnish Central Securities Depositary (FCSD), which maintains an electronic and official register of all securities transactions in Finland for virtually all companies listed on the Helsinki Exchanges (HEX). The data comprise daily trading account records of all Finnish investors. The sample period runs from January 1, 1995 through November 28, 2002, a period that includes both bull and bear markets. More detailed information on the data can be found in Grinblatt and Keloharju (2000, 2001). ${ }^{5}$

For the purposes of this study, the most significant advantage of the FCSD data is that it provides information on the institutional and legal type of each investor; by using this data I know the exact tax status of every investor in the market. All transactions moreover are tagged with a unique investor identification number that makes it possible to compute portfolio value, number of shares in the portfolio, and position in every stock for each domestic investor in the entire market on every day. All trades of an investor are aggregated on a daily basis by summing up all buys and sells in the same stock during the trading day. Hence, the daily change in the position of a stock is treated as one observation. The value of realized capital gains is calculated consistent with Finnish tax law on a trade-by-trade basis.

Grinblatt and Keloharju (2001) divide the FCSD data into six different investor categories: domestic households, domestic nonfinancial corporations, financial institutions, general government bodies, other nonprofit institutions, and foreigners. I follow this grouping with two exceptions. First, because mutual funds have a different tax status from other financial institutions, I put these investors in a category of their own. Second, I combine general government and other nonprofit institutions given their relatively modest importance in the Finnish stock market and small differences in their behavior as documented in Grinblatt and Keloharju (2001).

\footnotetext{
${ }^{5}$ The data in Grinblatt and Keloharju $(2000,2001)$ are for 1995-1996.
} 
The aggregate group of foreigners, which consists primarily of large institutional investors, such as international mutual and pension funds, accounts for $40-50 \%$ of the total trading volume of HEX. Foreigners trading in the Finnish stock market have an option to either register in their own name or execute trades via a domestic financial institution nominee account. Their trades appear in the data under the nominee institutions investor identification number, but with a separate flag for a nominee account trade. It is impossible to perform an investor level analysis on foreign investors not registered under their own names. As only a small fraction of all trades are executed by registered foreigners, I pool all foreigners in the empirical analysis.

The purchase price is unknown for all shares acquired prior to January 1, 1995 and for shares acquired during the sample period by means other than an open market purchase, equity offering, or merger. Computing total capital gains tax liability for an investor requires that I know the cost basis for all shares sold during the fiscal year. Thus, if an investor sells shares and no purchase price is available, all observations for that investor for the remainder of the fiscal year are lost. Capital gains for the remaining subsample of observations are calculated consistent with the tax law by correcting for splits, rights offerings, mergers, and bonus issues.

The FCSD data on securities transactions are supplemented with dividend and stock price data from the Helsinki Exchanges (HEX). Altogether, there are 926 ex-dividend day events. HEX share price data for open, close, bid, and ask prices are combined with HEX portfolio yield index logarithmic returns, and 12-month Helsinki interbank offered rate (HELIBOR, until the end of 1998) or 12-month EURIBOR (from the beginning of 1999) data to compute past arithmetic returns and betas for each individual stock. ${ }^{6}$ Like Bell and Jenkinson (2002), I use monthly betas to avoid problems caused by thin trading of the smallest stocks in my sample, but the data forces a compromise between the accuracy of beta estimates and the number of observations in the remaining sample. Therefore, a historical three-year window is selected to estimate betas instead of the more common five-year window. Financial statements data for the book value of assets is retrieved from Thomson/Datastream and augmented from annual reports.

The initial sample of 926 ex-dividend day events is reduced to 732 events, as some of the stocks did not trade either on the last cum-dividend day or the first ex-dividend day. Twelve exday events are lost because some of the stocks did not belong to the FCSD registry. Finally, there are 501 events in the sample when the stock beta is required to be known.

\footnotetext{
${ }^{6}$ Nokia has had a disproportionately large weight since the end of the 1990s, so I use the HEX Portfolio Yield Index (HPYI) with a 10\% value weight restriction, where available. HPYI is available only since January 1, 1996. Before that, I use the value-weighted HEX General Yield Index instead.
} 
Table 2

Ex-day price drop in Finland from 1995 to 2002

This table reports the magnitude of ex-dividend day price drop in Finland for various econometric specifications. The dependent variable is excess return on the ex-dividend day, $[(\mathrm{P}(\mathrm{ex})-\mathrm{P}(\mathrm{cum})) / \mathrm{P}(\mathrm{ex})]$ - market index return. Standard errors for coefficient estimates are reported in parentheses. Specification 1 yields results from the specification of Boyd and Jagannathan (1994) (BJ), where the ex-day price drop is regressed on dividend yield and a constant using cum- and ex-day closing prices. In specifications 2 to 8 , observations are scaled with estimated standard deviation of daily share price changes from the window [-241, -40] to compute a hetroskedasticity corrected estimate. In specifications 4 and 5, the coefficient is allowed to vary over time. Specifications 6 and 7 include only HEX main list companies, whereas specification 8 reports results estimated from a sample of HEX main list companies with dividend yield higher than $2 \%$. One observation is dropped from the data in specifications $2-8$ due to lack of return data to estimate standard deviation. Standard errors for coefficient estimates are reported in parentheses.

\begin{tabular}{|c|c|c|c|c|c|c|c|c|c|c|c|c|c|c|c|c|}
\hline \multirow{3}{*}{ Specification } & \multicolumn{6}{|c|}{ Simple BJ and heteroskedasticity corrected } & \multicolumn{4}{|c|}{ Annual estimations } & \multicolumn{6}{|c|}{ HEX main list company estimations } \\
\hline & \multicolumn{2}{|c|}{ EG close-close } & \multicolumn{2}{|c|}{ GLS close-open } & \multicolumn{2}{|c|}{ GLS close-close } & \multicolumn{2}{|c|}{$\begin{array}{l}\text { Annual close- } \\
\text { open }\end{array}$} & \multicolumn{2}{|c|}{$\begin{array}{l}\text { Annual close- } \\
\text { close }\end{array}$} & \multicolumn{2}{|c|}{$\begin{array}{l}\text { Main list close- } \\
\text { open }\end{array}$} & \multicolumn{2}{|c|}{$\begin{array}{l}\text { Main list close- } \\
\text { close }\end{array}$} & \multicolumn{2}{|c|}{$\begin{array}{l}\text { Main list close- } \\
\text { open high yield }\end{array}$} \\
\hline & 1 & & 2 & & 3 & & 4 & & 5 & & 6 & & 7 & & 8 & \\
\hline Intercept & 0.009 & $(0.002)$ & 0.357 & $(0.123)$ & 0.330 & $(0.091)$ & 0.318 & $(0.134)$ & 0.313 & $(0.098)$ & 0.337 & $(0.133)$ & 0.316 & $(0.094)$ & 0.446 & $(0.192)$ \\
\hline $\mathrm{D} / \mathrm{P}$ & -1.138 & $(0.034)$ & -1.037 & $(0.052)$ & -1.090 & $(0.038)$ & & & & & -1.039 & $(0.055)$ & -1.087 & $(0.039)$ & -1.067 & $(0.069)$ \\
\hline $1995^{*} \mathrm{D} / \mathrm{P}$ & & & & & & & -0.752 & $(0.140)$ & -0.767 & $(0.103)$ & & & & & & \\
\hline $1996 * \mathrm{D} / \mathrm{P}$ & & & & & & & -1.019 & $(0.130)$ & -0.977 & $(0.095)$ & & & & & & \\
\hline $1997^{*} \mathrm{D} / \mathrm{P}$ & & & & & & & -0.850 & $(0.149)$ & -1.024 & $(0.109)$ & & & & & & \\
\hline $1998 * \mathrm{D} / \mathrm{P}$ & & & & & & & -1.083 & $(0.166)$ & -1.228 & $(0.122)$ & & & & & & \\
\hline $1999 * \mathrm{D} / \mathrm{P}$ & & & & & & & -1.059 & $(0.156)$ & -1.207 & $(0.115)$ & & & & & & \\
\hline $2000 * \mathrm{D} / \mathrm{P}$ & & & & & & & -0.894 & $(0.076)$ & -1.016 & $(0.056)$ & & & & & & \\
\hline $2001 * \mathrm{D} / \mathrm{P}$ & & & & & & & -1.124 & $(0.078)$ & -1.170 & $(0.057)$ & & & & & & \\
\hline $2002 * \mathrm{D} / \mathrm{P}$ & & & & & & & -1.228 & $(0.090)$ & -1.189 & $(0.066)$ & & & & & & \\
\hline $\mathrm{R}^{2}$ & 0.60 & & 0.36 & & 0.53 & & 0.37 & & 0.54 & & 0.36 & & 0.55 & & 0.33 & \\
\hline F-test statistic & 1097.55 & & 402.25 & & 816.80 & & 53.23 & & 107.34 & & 358.18 & & 779.96 & & 237.68 & \\
\hline $\begin{array}{l}\text { Number of } \\
\text { observations }\end{array}$ & 732 & & 731 & & 731 & & 731 & & 731 & & 652 & & 652 & & 487 & \\
\hline
\end{tabular}




\section{Empirical Analysis}

\subsection{Ex-dividend day ratio}

I begin the empirical analysis by estimating the extent of the ex-dividend day price drop. Assuming that the expected ex-day ratio equals the realized ex-day ratio in my sample, analysis of the average realized ratio helps us to see which investor categories have an incentive to trade around the ex-day.

Table 2 reports the results for eight specifications, where excess return (stock return market index return) on the ex-day is regressed on a constant and dividend yield. I experiment by using ex-dividend day open and close prices for computing returns, by correcting for heteroskedasticity, by dropping all but main list and high-dividend yield companies from the sample, and by letting the dividend yield coefficient vary over time.

Point estimates vary from a price drop of 1.039 to 1.138 times the dividend paid. In three out of six single-factor regressions, the price drop does not significantly differ from unity at the $5 \%$ level. In the remaining three cases, the price drop is significantly higher than one. There is thus some evidence that the ex-dividend day ratio is modestly higher than one. The traditional interpretation would suggest that domestic taxable investors are the marginal investors, but their effective tax rate is lower than the nominal rate. For example, the coefficient for dividend yield in year 2002 in specification 4 translates to an effective capital gains tax rate of $18.6 \%$.

Boyd and Jagannathan (1994) and Bali and Hite (1998) have argued that the ex-day premium may be at least partially driven by stock price discreteness rather than merely by taxes. However, there are three factors that undermine this explanation. First, Bali and Hite (1998) explain only why the price drop may be less than the dividend. They do not explain why the exday premium is higher than one, as is observed in Table 2. Second, Liljeblom et al. (2001) have shown that the tick size restriction was not binding in the Finnish ex-dividend day returns during the partially overlapping period of 1994-1996. They find that only in 15 of 122 ex-dividend day events was the price change less than two ticks above or below the dividend. Third, since the beginning of 1999 all stock prices have been quoted in euros with a uniform tick size of 0.01 . This further diminishes the price discreteness effect, if any, in the latter part of my sample. 


\subsection{Who trades around the ex-dividend day?}

I perform two market level analyses to document the identity of investors trading around the ex-dividend day. The first analysis documents the relative trading volumes by investor category, and the second changes in the direction of trades.

In the first analysis, I compute gross and net trading volumes around the ex-day for each investor category. To prevent giving too much weight to Nokia in the analysis, I first calculate the gross proportion of the daily trading volume for each investor category $i$ in each event $j$ and then take the arithmetic average over all 732 ex-dividend day events. More formally, the gross proportion of investor category $i$ at event-date $t$ is defined as

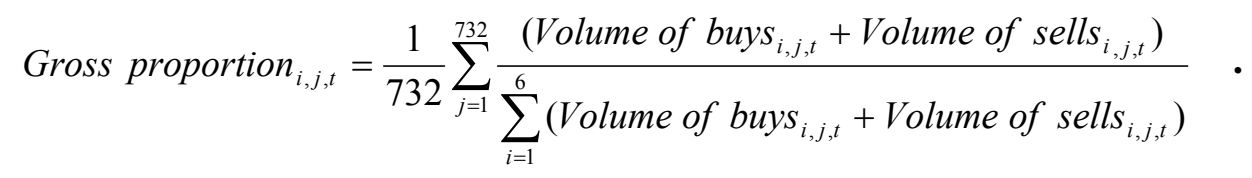

Correspondingly, net proportion is defined as

$$
\text { Net proportion }_{i, j, t}=\frac{1}{732} \sum_{j=1}^{732} \frac{\left(\text { Volume of buys }_{i, j, t}-\text { Volume of sells }_{i, j, t}\right)}{\left.\frac{1}{2} \sum_{i=1}^{6} \text { Volume of buys }_{i, j, t}+\text { Volume of sells }_{i, j, t}\right)} \text {. }
$$

I choose an event window of 22 days for the initial analysis. The window consists of the last cum-dividend and the first ex-dividend day plus 10 days on both sides. This selection is consistent with the hypothesis that some investors time their trades around the ex-dividend day within a broader window than would be predicted under the assumptions of a perfect capital market and fully rational investors. The results for both gross and net volumes are reported in Table 3.

Clearly, foreign investors dominate the market around the ex-dividend day: they account for over $40 \%$ of the gross trading volume. The second-largest category is domestic households (26\%) followed by nonfinancial corporations with a $16 \%$ share of the total volume. Mutual funds account for roughly $2.5 \%$ of the gross volume, but they double their share on the last cumdividend and the first ex-dividend day.

I also perform robustness checks by using the proportional number of trades instead of proportional volume and by dividing ex-day events to quintiles by dividend yield. The conclusions on the relative importance of different investor groups trading around the ex-day remain unchanged. 
Table 3

Gross and net trading volume by investor category

The table reports the average gross and net relative trading volume around the ex-dividend date. The proportion of gross volume is defined as the average of the buys and sells by the investor category divided by total trading volume. The net proportion of the trading volume for each investor category is calculated as (Volume of buy transactions Volume of sell transactions) / Total volume. Event-date 0 corresponds to the last cum-dividend day and event-date 1 to the first ex-dividend day.

\begin{tabular}{|c|c|c|c|c|c|c|}
\hline \multicolumn{7}{|c|}{ Panel A: Gross volume } \\
\hline \multirow[t]{2}{*}{ Event-date } & \multicolumn{3}{|c|}{ Domestic taxable investors } & \multicolumn{2}{|c|}{ Domestic nontaxable investors } & \multirow[t]{2}{*}{ Foreigners } \\
\hline & $\begin{array}{l}\text { Nonfinancial } \\
\text { corp. }\end{array}$ & Households & Financial corp. & Mutual funds & $\begin{array}{c}\text { Nonprofit } \\
\text { institutions }\end{array}$ & \\
\hline-10 & 0.113 & 0.276 & 0.090 & 0.028 & 0.042 & 0.451 \\
\hline-9 & 0.130 & 0.248 & 0.098 & 0.026 & 0.038 & 0.459 \\
\hline-8 & 0.126 & 0.290 & 0.096 & 0.022 & 0.031 & 0.434 \\
\hline-7 & 0.118 & 0.296 & 0.090 & 0.025 & 0.033 & 0.435 \\
\hline-6 & 0.115 & 0.287 & 0.086 & 0.027 & 0.034 & 0.449 \\
\hline-5 & 0.133 & 0.268 & 0.098 & 0.029 & 0.038 & 0.434 \\
\hline-4 & 0.119 & 0.281 & 0.088 & 0.026 & 0.034 & 0.451 \\
\hline-3 & 0.123 & 0.280 & 0.088 & 0.025 & 0.038 & 0.446 \\
\hline-2 & 0.122 & 0.286 & 0.082 & 0.026 & 0.036 & 0.447 \\
\hline-1 & 0.131 & 0.282 & 0.085 & 0.029 & 0.029 & 0.444 \\
\hline 0 & 0.158 & 0.262 & 0.089 & 0.052 & 0.031 & 0.406 \\
\hline 1 & 0.155 & 0.256 & 0.105 & 0.050 & 0.028 & 0.407 \\
\hline 2 & 0.119 & 0.298 & 0.094 & 0.021 & 0.035 & 0.430 \\
\hline 3 & 0.118 & 0.270 & 0.097 & 0.018 & 0.035 & 0.456 \\
\hline 4 & 0.115 & 0.270 & 0.083 & 0.026 & 0.027 & 0.478 \\
\hline 5 & 0.113 & 0.272 & 0.081 & 0.024 & 0.033 & 0.476 \\
\hline 6 & 0.110 & 0.268 & 0.087 & 0.026 & 0.033 & 0.474 \\
\hline 7 & 0.120 & 0.275 & 0.101 & 0.025 & 0.037 & 0.442 \\
\hline 8 & 0.125 & 0.284 & 0.087 & 0.029 & 0.039 & 0.436 \\
\hline 9 & 0.122 & 0.281 & 0.094 & 0.026 & 0.038 & 0.438 \\
\hline 10 & 0.114 & 0.295 & 0.085 & 0.023 & 0.046 & 0.436 \\
\hline 11 & 0.116 & 0.299 & 0.094 & 0.021 & 0.039 & 0.431 \\
\hline \multicolumn{7}{|c|}{ Panel B: Net volume } \\
\hline \multirow[t]{2}{*}{ Event-date } & \multicolumn{3}{|c|}{ Domestic taxable investors } & \multicolumn{2}{|c|}{ Domestic nontaxable investors } & Foreigners \\
\hline & $\begin{array}{c}\text { Nonfinancial } \\
\text { corp. }\end{array}$ & Households & Financial corp. & Mutual funds & $\begin{array}{c}\text { Nonprofit } \\
\text { institutions }\end{array}$ & \\
\hline-10 & 0.008 & 0.009 & -0.009 & -0.008 & 0.003 & -0.006 \\
\hline-9 & 0.019 & 0.015 & 0.001 & -0.009 & -0.002 & -0.023 \\
\hline-8 & 0.015 & 0.006 & -0.011 & -0.005 & -0.001 & -0.011 \\
\hline-7 & -0.004 & 0.016 & 0.007 & -0.007 & 0.003 & -0.018 \\
\hline-6 & -0.012 & 0.042 & 0.008 & -0.008 & -0.005 & -0.024 \\
\hline-5 & -0.017 & 0.037 & 0.003 & -0.005 & 0.003 & -0.015 \\
\hline-4 & -0.010 & 0.027 & -0.003 & -0.009 & 0.003 & -0.004 \\
\hline-3 & -0.015 & 0.026 & 0.004 & -0.003 & -0.006 & -0.017 \\
\hline-2 & 0.003 & 0.036 & -0.006 & 0.002 & -0.005 & -0.028 \\
\hline-1 & -0.011 & 0.047 & 0.016 & -0.019 & 0.002 & -0.028 \\
\hline 0 & 0.101 & 0.057 & -0.009 & -0.065 & -0.010 & -0.069 \\
\hline 1 & -0.098 & -0.059 & 0.022 & 0.062 & 0.009 & 0.064 \\
\hline 2 & -0.031 & -0.005 & 0.012 & 0.005 & 0.011 & 0.006 \\
\hline 3 & -0.029 & 0.012 & 0.012 & 0.004 & 0.005 & -0.001 \\
\hline 4 & -0.004 & -0.049 & 0.012 & 0.000 & 0.016 & 0.014 \\
\hline 5 & -0.005 & -0.032 & 0.015 & -0.002 & -0.005 & 0.016 \\
\hline 6 & -0.018 & -0.027 & 0.016 & 0.010 & 0.001 & 0.007 \\
\hline 7 & -0.027 & -0.024 & 0.022 & -0.011 & 0.018 & 0.022 \\
\hline 8 & 0.000 & -0.035 & 0.008 & -0.003 & 0.004 & 0.015 \\
\hline 9 & 0.019 & -0.061 & 0.007 & 0.012 & -0.002 & 0.014 \\
\hline 10 & -0.007 & -0.050 & 0.011 & 0.009 & 0.019 & 0.012 \\
\hline 11 & 0.002 & -0.032 & 0.022 & -0.005 & 0.014 & -0.001 \\
\hline
\end{tabular}


The net volume figures reveal that nonfinancial corporations and households sharply shift from the buy side on the last cum-dividend day to the sell side on the first ex-dividend day. The reverse is true for foreigners and for mutual funds. Both observations are consistent with the dynamic tax clientele explanation (e.g., Michaely and Vila, 1995), which predicts that differences in tax rates drive trading behavior around the ex-dividend day.

But do the trading clienteles have an impact on the ex-dividend day premium? Michaely and Vila (1995) show that the expected ex-day premium is the sum of two distinct components. The first component is the average dividend preference ratio of all agents trading around the exdividend day, weighted by the tax-adjusted risk aversion of each investor. The second component adjusts for the risk involved in ex-day trading. Assuming constant risk aversion across investors as in Michaely and Vila (1995, p. 189), the first component of the expected premium can be expressed as a linear combination of the proportions of different investor categories trading on the ex-day. In an unreported analysis, I regress ex-dividend day premium on relative proportions of trading volume, but find no evidence that trading clienteles have an impact on the ex-day premium.

I complement the analysis of volumes by investigating within-group changes in trading behavior around the ex-dividend day. The buy/sell ratio for each investor category $i$ for each event-day $t$ is computed as

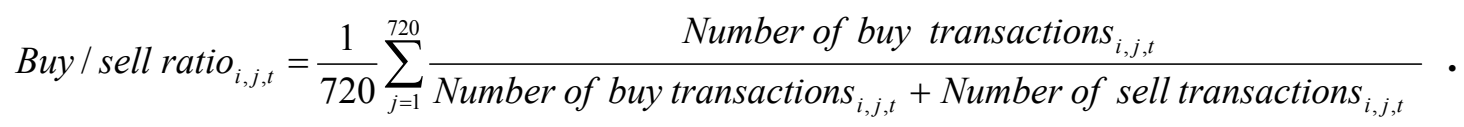

The buy/sell ratio in essence describes whether the median investor in a particular category is on the buy side or on the sell side of the market. Figure 1 plots the ratios by investor category for all events and for the highest and lowest dividend yield quintiles. Table 4 reports $t$-test statistics for the equality of buy/sell ratios on the last cum-dividend day and the first ex-dividend day by investor category.

The results for buy/sell ratios support the analysis with regard to gross and net volumes and are consistent with the dynamic tax clientele explanation. Domestic investors with a preference for dividends clearly accelerate their buys before a stock goes ex-dividend and increase sells after the stock has gone ex-dividend. Foreigners with a preference for capital gains sell shares cumdividend and buy ex-dividend. A closer look reveals that the domestic financial corporations are rather active in ex-day trading, but the graph is flat in Figure 1, because these investors engage in 
short-term roundtrip trading to both directions in almost equal magnitude. Of 14,764 domestic financial corporations trading around the ex-dividend day, 1296 investors bought shares cumdividend and sold ex-dividend within the 22-day window, whereas 1330 investors sold shares cum-dividend and bought ex-dividend.

Domestic Taxable Investors

Domestic households

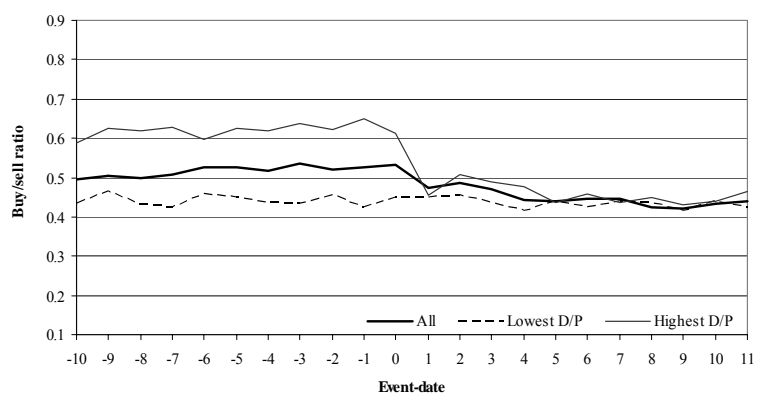

Domestic nonfinancial corporation

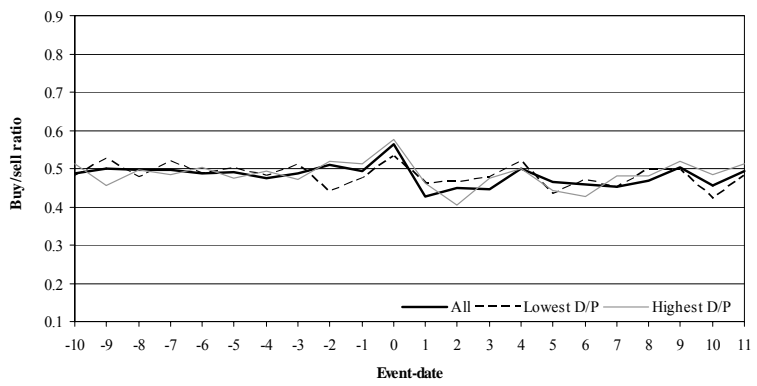

Foreigners

Domestic financial corporations

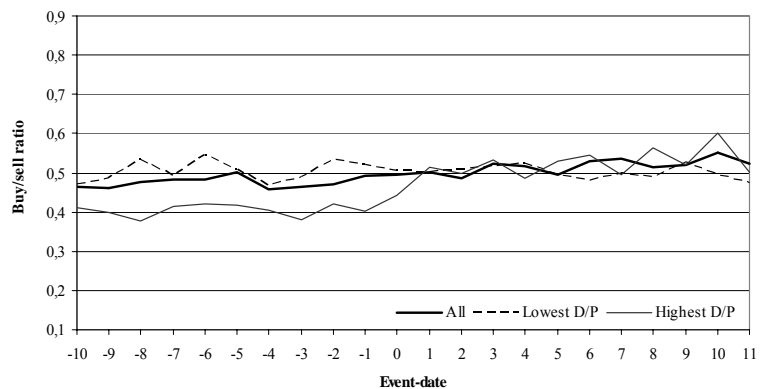

Nontaxable Investors

Nontaxed nonprofit institutions

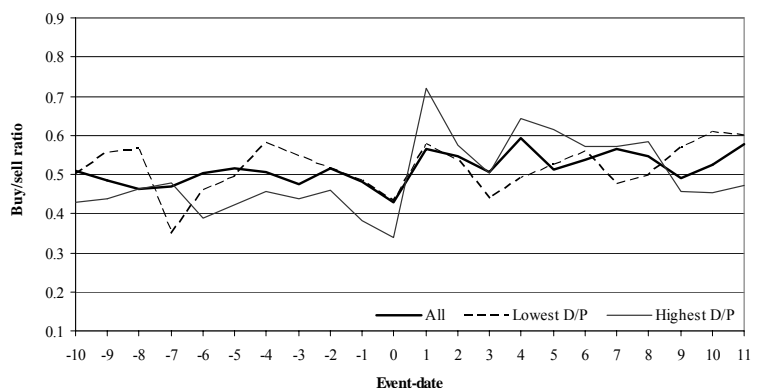

Mutual funds

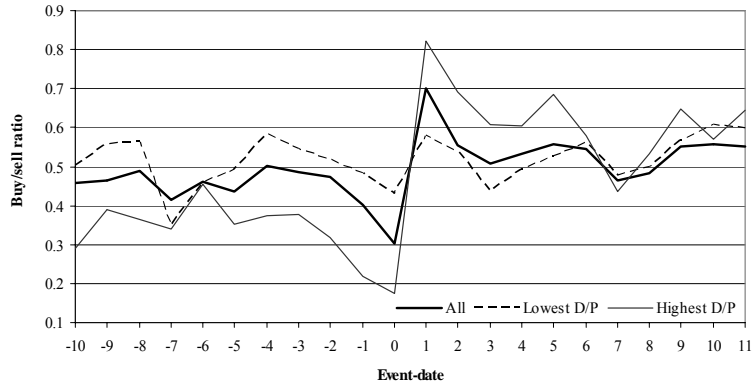

Foreigners

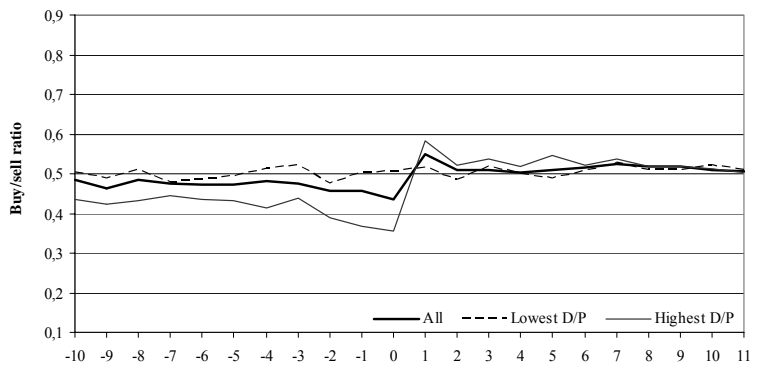

Fig. 1. Trading around ex-dividend day by investor category. The figures plot the relative frequencies of buy and sell transactions by investor group around the ex-dividend day. The buy/sell ratio for an investor category is defined as (\# of buy transactions)/( \# of buy transactions + \# of sell transactions) and is plotted on the y-axis, weighting each exdividend day event equally. The results are based on the full sample of 926 ex-dividend events. Event date 0 corresponds to the last date a stock trades cum-dividend and event date 1 to the first date the stock trades ex-dividend. Results are reported for all events as well as for the lowest and the highest dividend yield quintile. 
Table 4

$t$-test for equality of means in buy/sell ratio on event days 0 and 1

Panel A reports the change in buy/sell ratio between the last cum-dividend day and the first ex-dividend day by investor category. Buy/sell ratio is defined as (\# of buy transactions) / (\# of buy transactions + \# of sell transactions). Two-tailed $t$-statistics are reported in Panel B. The null hypothesis is that buy/sell ratios on the last cum-dividend and the first exdividend days are equal.

\begin{tabular}{|c|c|c|c|c|c|c|}
\hline & \multicolumn{3}{|c|}{ Domestic taxable investors } & \multicolumn{2}{|c|}{$\begin{array}{l}\text { Domestic nontaxable } \\
\text { investors }\end{array}$} & \multirow[t]{2}{*}{ Foreigners } \\
\hline & $\begin{array}{l}\text { Nonfinancial } \\
\text { corporations }\end{array}$ & Households & $\begin{array}{c}\text { Financial } \\
\text { corporations }\end{array}$ & $\begin{array}{l}\text { Mutual } \\
\text { funds }\end{array}$ & $\begin{array}{l}\text { Nonprofit } \\
\text { institutions }\end{array}$ & \\
\hline \multicolumn{7}{|c|}{ Panel A: Difference in buy/sell ratio } \\
\hline \multicolumn{7}{|c|}{$\mathrm{D} / \mathrm{P}$ quintiles: } \\
\hline Lowest & -0.072 & 0.002 & -0.004 & 0.148 & -0.025 & 0.009 \\
\hline 2 & -0.139 & 0.011 & -0.108 & 0.440 & -0.027 & 0.056 \\
\hline 3 & -0.235 & -0.063 & 0.005 & 0.439 & 0.161 & 0.160 \\
\hline 4 & -0.139 & -0.093 & 0.076 & 0.416 & 0.197 & 0.153 \\
\hline Highest & -0.114 & -0.157 & 0.070 & 0.650 & 0.382 & 0.229 \\
\hline All & -0.137 & -0.061 & 0.006 & 0.400 & 0.135 & 0.113 \\
\hline \multicolumn{7}{|c|}{ Panel B: $t$-values } \\
\hline \multicolumn{7}{|c|}{ D/P quintiles: } \\
\hline Lowest & -1.91 & 0.07 & -0.12 & 2.10 & -0.36 & 0.38 \\
\hline 2 & -2.84 & 0.29 & -2.37 & 6.23 & -0.31 & 2.03 \\
\hline 3 & -5.16 & -1.75 & 0.10 & 6.51 & 2.05 & 5.91 \\
\hline 4 & -2.94 & -2.98 & 1.46 & 4.93 & 2.27 & 4.59 \\
\hline Highest & -2.70 & -5.57 & 1.59 & 9.95 & 4.99 & 6.81 \\
\hline All & -6.94 & -4.22 & 0.28 & 12.23 & 3.78 & 8.76 \\
\hline
\end{tabular}

The change in buy/sell ratio is particularly pronounced for mutual funds, which are selling stocks cum-dividend and buying ex-dividend. The change in buy/sell ratio for mutual funds is most extreme in the highest dividend yield quintile, with an overnight change from 0.82 to 0.17 . Nonprofit institutions such as municipalities, foundations, and religious institutions also trade around the ex-day, but the change in buy/sell ratio is less pronounced for this group.

Differences in trading behavior are likely explained by differences in regulatory risk and incentives. By law, nonprofit institutions cannot engage in for-profit activities without jeopardizing their tax-exempt status. A mutual fund, on the other hand, is by law bound to act in the best interest of its shareholders, and its status as an untaxed entity does not depend on its trading behavior. Moreover, the incentives to perform in the mutual fund industry are likely to be considerably greater than those in the nonprofit sector.

The observed behavior of mutual funds is consistent with Kalay (1982), who argues that investors with a dividend preference ratio of 1 should engage in short-term trading as long as the 
price drop on the ex-day does not equal unity. Short-term trading activity by mutual funds may be profitable because the estimated ex-dividend day drop is marginally higher than unity in three specifications reported in Table 2.

\subsection{Arbitrage by mutual funds}

Do mutual funds make any money on ex-dividend arbitrage? What are the risks involved?

To answer these questions, I look at the sales by mutual fund on the last cum-dividend day with a corresponding buy on the first ex-dividend day. Descriptive statistics for this arbitrage activity are presented in Table 5.

Table 5

Descriptive statistics on arbitrage by mutual funds

This table reports descriptive statistics on sell cum-dividend, buy ex-dividend strategy by mutual funds. The gain from sell-buy arbitrage is calculated as follows:

Value of holdings sold cum - value of dividend paid to sold stocks - value of stocks bought ex - (\# of shares sold cum - \# of shares bought ex) x ex-day close

Value of trade, dividend yield, bid/ask spread, and beta are equally-weighted averages, calculated from observations when a mutual fund sells cum and buys ex. Average (median) gain / value of shares sold cum-dividend measures the average (median) relative gain from a trade with respect to the value of shares sold cum-dividend by a mutual fund, defined as (gain from transaction) / (price at cum-day* volume sold). All profitability statistics are computed before transaction costs.

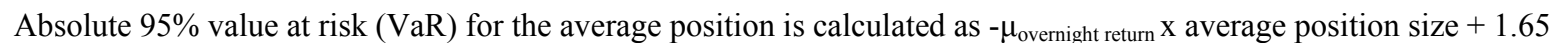

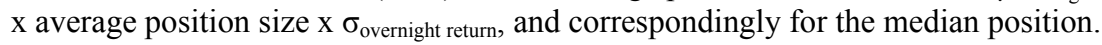

Panel A: Traded stock characteristics 
As predicted by Kalay (1982), arbitrage activity by nontaxable mutual funds is concentrated in stocks with high dividend yields and low transaction costs. Arbitrage is also higher in stocks with betas of less than unity, suggesting that risk matters in the choice of arbitraged stock. As might be deduced from the ex-dividend day ratio results reported earlier, this arbitrage activity tends to yield only modest profits. The realized median gain from an arbitrage trade is positive (sign test $p<0.001$ ) at EUR 639 before transaction costs.

A graph of the net profit per investor and the number of trades in Figure 2 reveals that most funds are successful in generating profits over the sample period. The most successful fund manager increased the value of the managed fund by over a quarter of a million euros.

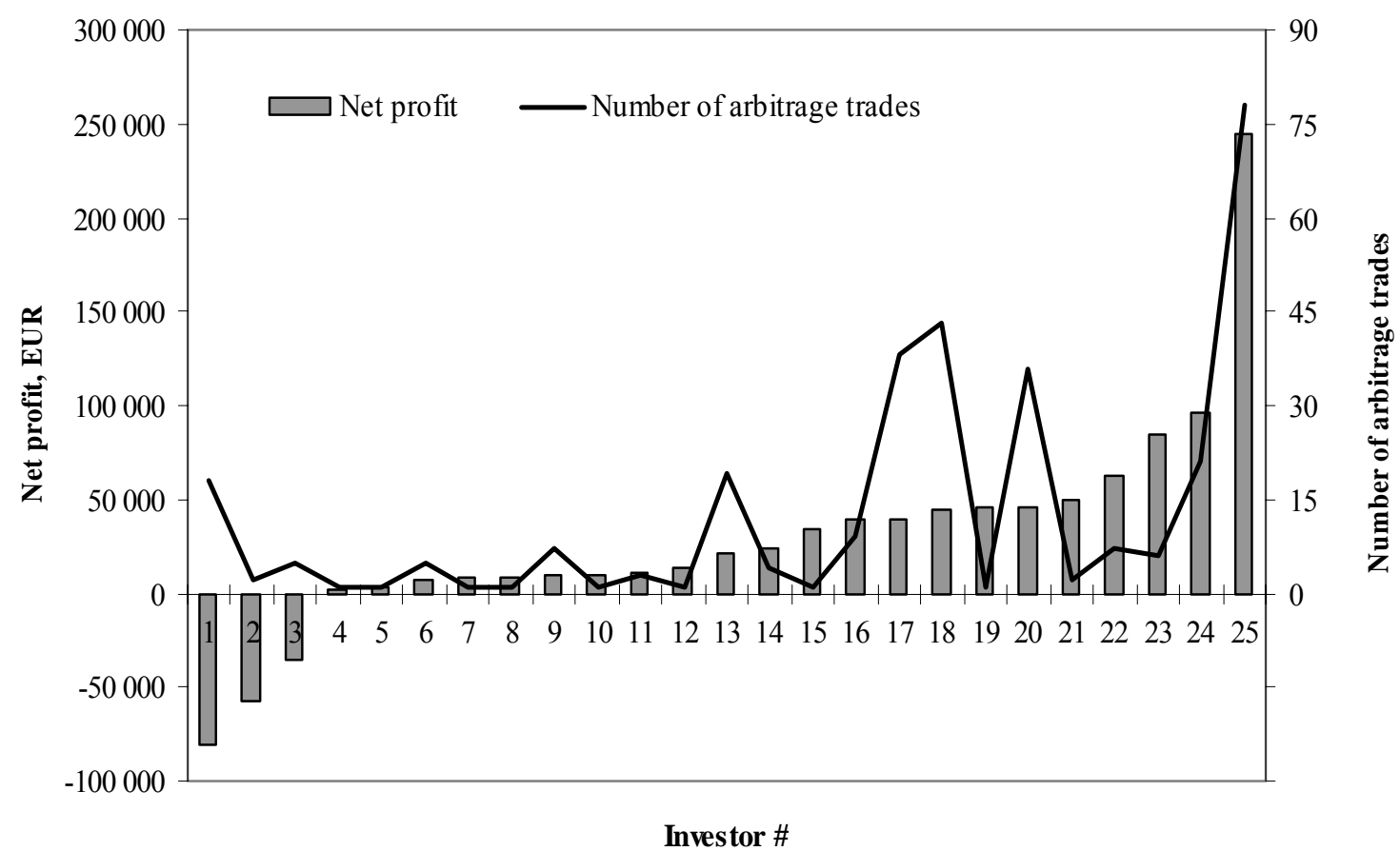

Fig. 2. Profitability and distribution of arbitrage trades by mutual funds. The left y-axis indicates the profitability of arbitrage trades for each investor, aggregated over the sample period. The right y-axis corresponds to the number of sell-buy arbitrage events by the investor. The results are based on 25 mutual funds engaging in overnight sell-buy arbitrage around ex-day events.

This arbitrage activity is not excessively risky. The $95 \%$ absolute value at risk for the average (median) overnight position of EUR 319,093 (EUR 240,424) is EUR 24,482 (EUR 19,628). Given the expected profit with the modest risk involved, this activity is rather profitable, at least in the long run. The scale of arbitrage activity by mutual funds is rather small though: on average only one round-trip transaction in every three stocks going ex-dividend. 
5.4. Determinants of ex-dividend day trading behavior: sample construction and descriptive statistics

Eades, Hess, and Kim (1984) observe abnormal returns around the ex-dividend day, which Allen and Michaely (2004) argue to be caused by investors who trade several days before and after the ex-dividend day instead of trading only on the last cum-dividend and the first ex-day. To see if this is indeed the case, it is necessary to investigate how tax arbitrage investors time their trades around the ex-dividend day. Toward this end, I examine all observations with a strictly positive change for an investor in the position of a stock going ex-dividend in the 11 day-window before the ex-dividend day and then a strictly negative change in the position in the 11-day window after the ex-dividend day.

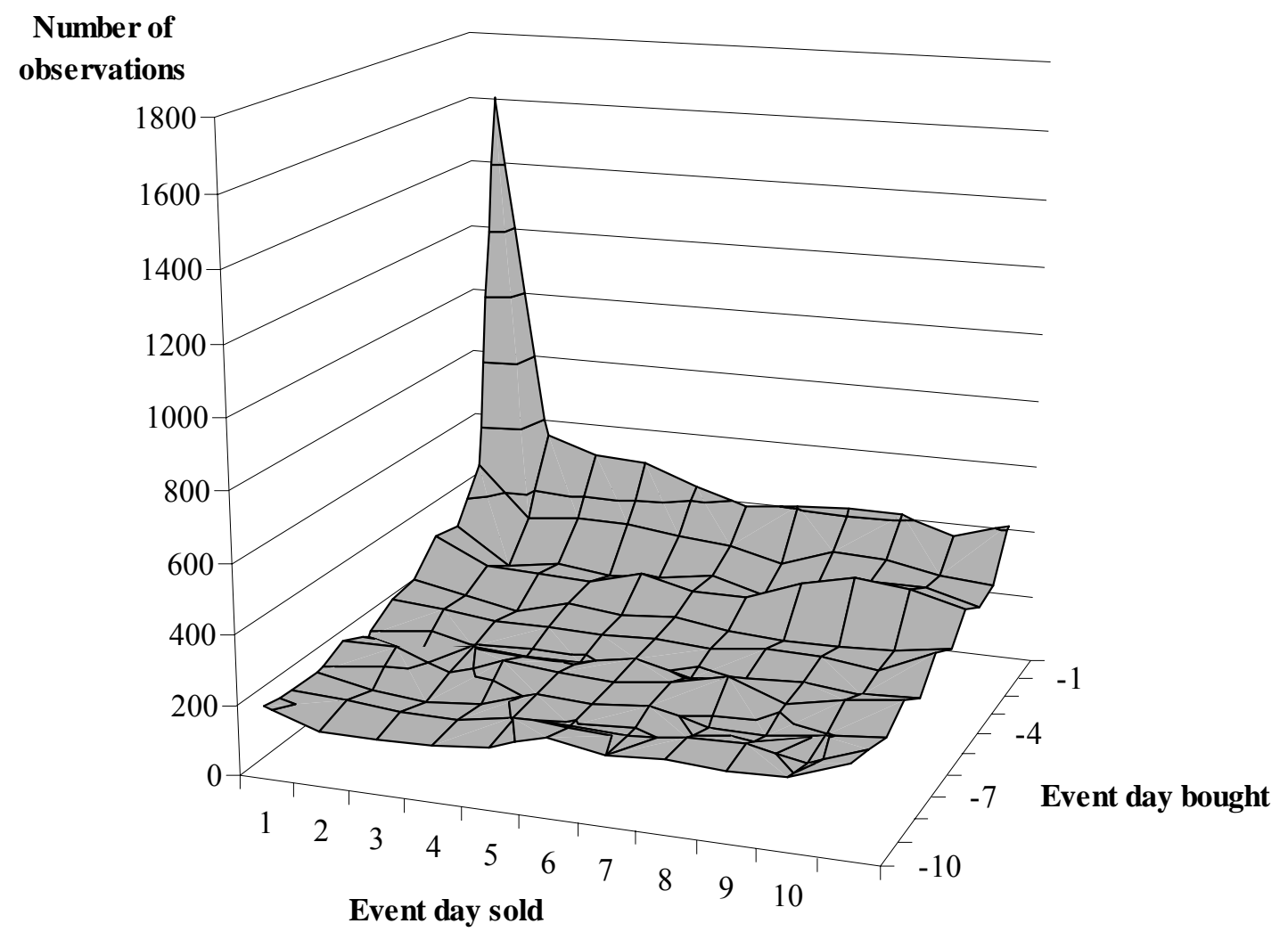

Fig. 3. Timing of trades around the ex-dividend day. This figure depicts the distribution of trades around the exdividend date in the full sample of 926 ex-dividend events. If an investor accumulates a position in a stock cumdividend and subsequently reduces the position in the same stock ex-dividend in the [-10, 11] (inclusive) day window around the event, a transaction is classified as an observation. Z-axis represents the day the investor first increased position in the stock before ex-dividend date, $\mathrm{X}$-axis the last day the investor reduced position in the stock after exdate, and $\mathrm{Y}$-axis the number of observations. If the investor buys the same stock cum-dividend or sells ex-dividend in several days around an ex-dividend day event, one buy and one sell is selected at random. 
Panel A: Evolution of tax arbitrage activity over time

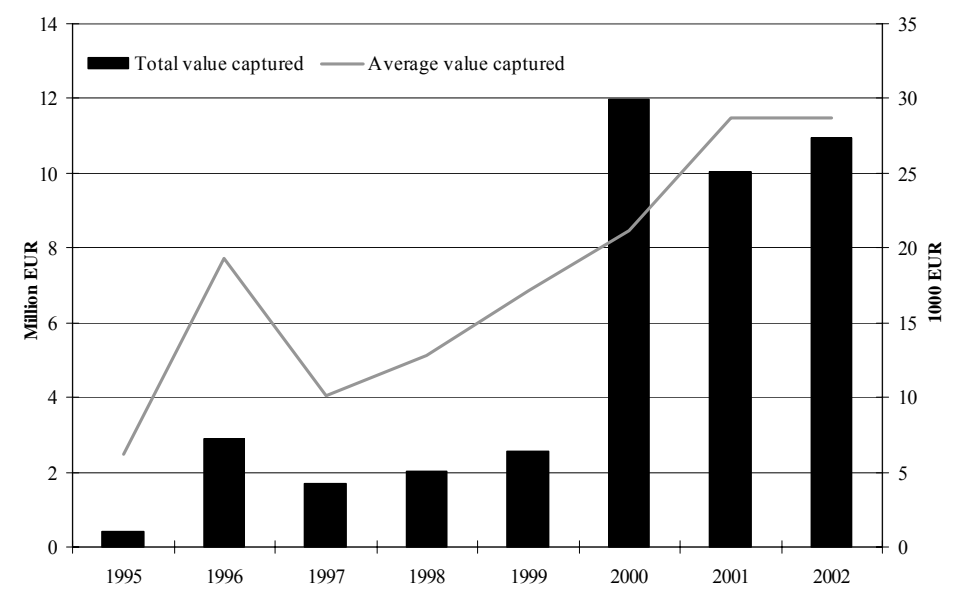

Panel B: Number of investors engaging in buy-sell tax arbitrage around ex-dividend day

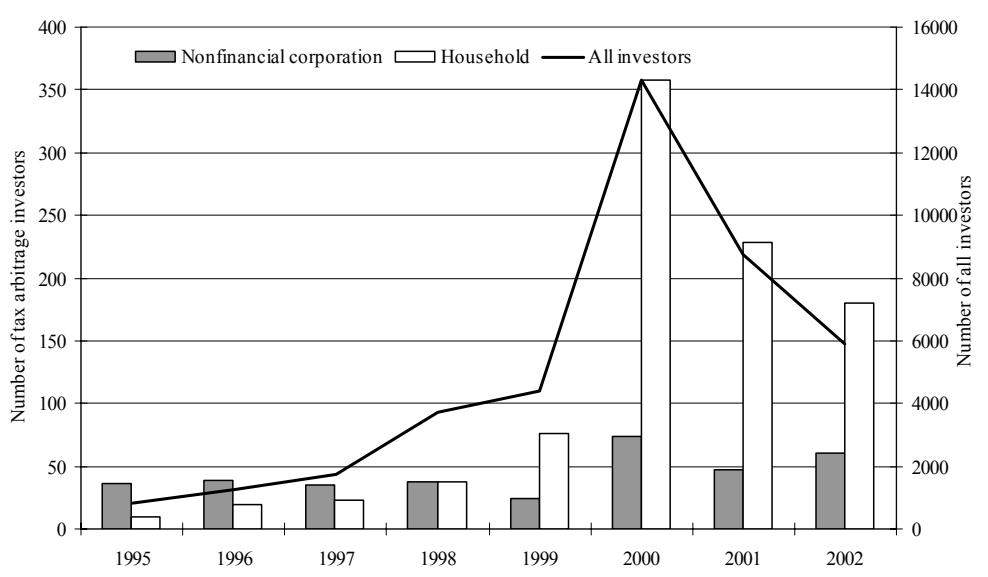

Panel C: Number of buy-sell events per investor

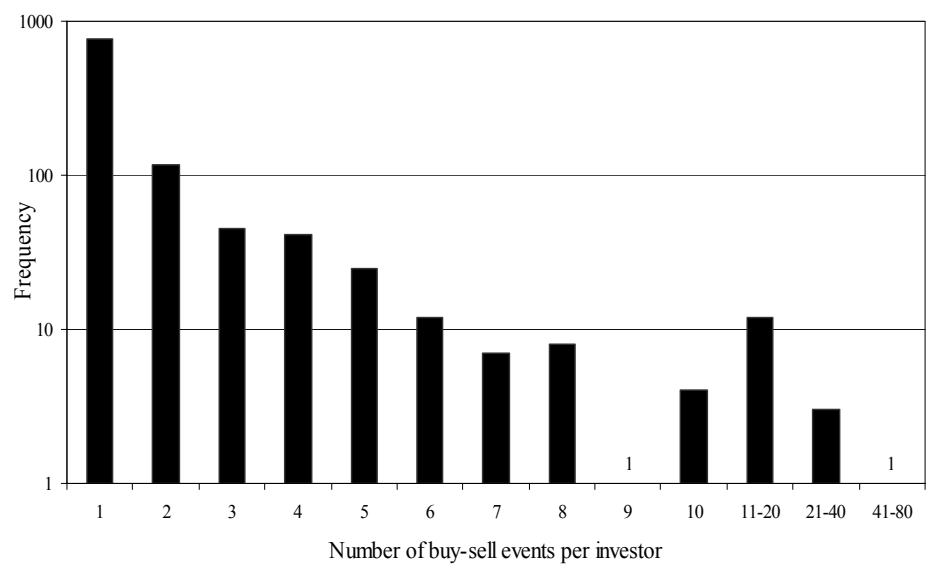

Fig. 4. Patterns of tax arbitrage activity. These figures exhibit descriptive statistics on ex-dividend day tax arbitrage by domestic taxable investors over the full sample of 926 ex-dividend day events. An investor is classified as an arbitrageur every time he accumulates position in a stock on the last cum-dividend day and subsequently decreases position in the same stock on the first ex-day. Panel A presents the total annual and average value captured by multiplying the number of shares bought on the last cum-dividend day and subsequently sold on the ex-day by dividend per share. Panel B depicts the number of investors engaging in tax arbitrage in a given year and the total number of investors trading around the ex-dividend date. Panel $\mathrm{C}$ shows how many buy-sell tax arbitrage events there are per investor in the sample. 
Figure 3 plots the distribution for the timing of buy cum-dividend sell ex-dividend transactions by all Finnish investors. ${ }^{7}$

As can be observed from the spike at the far-left corner of Figure 3, short-term trades are concentrated on the last cum-dividend and the first ex-dividend day. I single out for future analysis the overnight trades by domestic households and nonfinancial corporations, categories shown earlier to accelerate buys cum-dividend and sells ex-dividend. The overnight selection is consistent with the assumption that very few investors are likely to hold shares going ex-dividend overnight on the last cum-dividend day for other than tax reasons. This assumption might not hold in a broader event window.

Domestic households and nonfinancial corporations account for over $40 \%$ of the total trading volume during the sample period and they shift from buy to sell side after a stock has gone ex-dividend. To understand how the volume of tax arbitrage activity has evolved over time and how the degree of activity is distributed across investors, I plot in Figure 4 three graphs on tax arbitrage activity by domestic households and nonfinancial corporations.

My first observation is that the total amount of tax arbitrage activity has increased over time. However, despite of this, the majority of investors trading around the ex-dividend day are not short-term tax arbitrageurs. For example, in year 2002 only 241 out of 5894 investors trading around the ex-dividend day were overnight domestic household or nonfinancial corporate traders.

Second, the number of tax arbitrage transactions per investor is highly skewed to the left: $85 \%$ of investors traded only once or twice during the sample period (two first bars in Panel C), but these investors account for $84 \%$ of the tax arbitrage trading volume.

To supplement the sample of tax arbitrage trades with a control group, I pick all overnight trades not related to ex-dividend day trading by the investors in my sample. In essence, I am comparing the determinants of ex-day trades against other overnight trades by the very same investors. The pooled sample consists initially of 48,882 trades, but drops to 30,492 for missing price and return data reasons mostly because historical returns for three years are required to compute betas.

Table 6 reports descriptive statistics for the constructed sample. Both investor level and firm level variables are used in subsequent analyses. The investor level variables include a dummy for nonfinancial corporations, the logarithm of market value for all shares in the portfolio one day

\footnotetext{
${ }^{7}$ I perform the same analysis separately for different investor categories, and find the results to be qualitatively similar. Plots of the same graph for trades by investors selling cum-dividend and buying ex-dividend transactions reveal an identical overnight spike in the timing of trades.
} 
before the trade, and the percentage weight of the traded stock in the portfolio one day prior to trade. The variable for capital gains is defined as

$$
\text { Capital gains }=\frac{\text { Realized capital gains year to date }}{\mid \text { Realized capital gains year to date } \mid+ \text { Value of portfolio }}
$$

The variable measures the expected capital gains tax liability of an investor in the fiscal year of the trade, normalized by the investor's portfolio value. To avoid very high variation in the variable, the absolute value of capital gains is included in the denominator. As described in Section 4, capital gains cannot be estimated for all observations in the full sample. The remaining subsample consists of 2,561 observations.

The firm level variables are dividend yield (dividend from the last fiscal year divided by the current market price of the stock), bid/ask spread [defined as 2(ask - bid)/(ask + bid)], beta (3year historical monthly rolling beta), and idiosyncratic risk (standard deviation of the residual term of beta estimation regression divided by the standard deviation of the market index). Standard deviation of the market index is estimated from daily market returns around the trade, using a window of $[-10,10]$, inclusive.

I control for year, sex, investor age, and the investor's log-number of overnight trades in the sample. $^{8}$ The last variable is included by sample construction. An investor can execute an overnight ex-day trade in a stock only once a year, while the control observations are from all other trading days. This limited opportunity for ex-day trading causes the ex-day trading probability to be a function of trading activity, which must be controlled for.

There are two points worth noting in Table 6 . First, the relatively high average value of beta (1.19) is driven by overnight holdings in shares of Nokia; when all trades in Nokia A and K shares are removed from the sample, the average beta drops to 1.03 .

Second, the average and median values for the number of shares and for portfolio value clearly indicate that the sample consists of rather wealthy and well-diversified investors. For example, the median portfolio value at the end of 1998 for all Finnish investors (roughly the time series midpoint of the FCSD data) was EUR 5,638 for nonfinancial corporations and EUR 2,224 for domestic households, while the respective figures are EUR 828,000 and EUR 45,880 for the

\footnotetext{
${ }^{8}$ Although correlated with portfolio size $(\rho=0.46)$, including log-number of trades in the analysis does not signal on multicollinearity problems. The highest variance inflator factor statistics (VIFs) have values well under 5 where 10 is typically considered a critical value.
} 
tax arbitrageurs. Furthermore, the median household and nonfinancial corporate investor holds only one stock in the full sample, and the median tax arbitrageur holds nine stocks.

Table 6

Descriptive statistics of the sample of tax arbitrage trades

This table reports descriptive statistics on the sample of tax arbitrage and other overnight (control observation-) trades by domestic taxable investors. The four first investor level statistics are based on equally weighted data, where one investor is treated as one observation. The rest of the statistics are based on trade-weighted statistics, one trade (aggregated on daily basis) representing one observation.

\begin{tabular}{llllllll}
\hline Mean & Median & Std.Dev. & Skewness & Kurtosis & Min & Max & N \\
\hline \multicolumn{7}{c}{ Panel A: Investor level statistics } \\
\hline
\end{tabular}

Nonfinancial corporate investors

Household investors

- of which males

- of which females

Age

45.426

44.000

11.964

0.119

0.253

1.000

91.000

Nonfinancial corporation

$\begin{array}{lll}0.576 & 1.000 & 0.494\end{array}$

$-0.306$

1.094

0.000

$1.000 \quad 30,492$

dummy

Portfolio value,

5.251

0.156

15.396

$5.472 \quad 55.545 \quad 0.000$

$375.817 \quad 30,492$

Weight in target stock

0.079

0.001

0.181

$0.448 \quad 11.546$

$-1.000$

$1.000 \quad 30,492$

Capital gains

0.052

0.019

0.316

0.387

$6.868-1.000$

$\begin{array}{lrr}821.280 & 240.000 & 1316.350\end{array}$

2.120

$6.121 \quad 1.000$

$1.000 \quad 2,561$

Number of shares in

16.938

$9.000 \quad 21.943$

2.165

7.117

0.000

$4331.000 \quad 30,492$

portfolio

Panel B: Firm level statistics

$\begin{array}{lrllrrrrr}\text { Dividend yield } & 0.036 & 0.021 & 0.060 & 6.563 & 61.366 & 0.000 & 0.914 & 30,492 \\ \text { Bid/ask spread } & 0.009 & 0.004 & 0.015 & 6.307 & 92.234 & 0.000 & 0.400 & 30,492 \\ \text { Beta } & 1.188 & 1.131 & 0.591 & 0.734 & 4.534 & -1.188 & 3.361 & 30,492 \\ \text { Idiosyncratic risk/ } & 2.013 & 1.982 & 0.972 & 8.597 & 164.904 & 0.217 & 22.119 & 30,492\end{array}$

Panel C: Other

\begin{tabular}{lllllllll}
$\begin{array}{l}\text { Daily standard deviation } \\
\text { market index }\end{array}$ & 0.014 & 0.013 & 0.006 & 0.654 & 2.681 & 0.004 & 0.029 & 30,492 \\
\hline
\end{tabular}


Table 7

Choice of arbitrage stock: stocks bought on last cum-day and sold on first ex-day

This table reports the results for the choice of tax arbitrage stock. The binary dependent variable has the value of 1 if an investor accumulates position in a stock going ex-dividend on the last cum-dividend day and subsequently reduces position in the same stock on the first ex-dividend day. The control group coded as zeros consists of all other overnight transactions by the same investors. Beta is estimated from monthly historical returns over a period of 3 years. Idiosyncratic risk is the residual term from the regression of beta, scaled with standard deviation of the market index. Dividend yield is the cash dividend per share divided by last closing price, whereas bid-ask spread is defined as 2(ask-bid)/(ask+bid). Ln (portfolio value) is the natural logarithm of the portfolio value by an investor on the day before the trading day. Nonfinancial corporation dummy has the value of 1 , if the investor is a nonfinancial corporation, 0 if a household. Weight in target stock is the value of holdings in the traded stock divided by total portfolio value one day before the transaction. Capital gains is defined as (realized capital gains year to date) / (|realized capital gains year to date + value of portfolio). Ln (number of trades) is the natural logarithm of the number of overnight trades the investor has in the sample. Standard deviation of market index is the daily standard deviation of market index calculated from $[-10,10]$ window around the trade. Specification 1 is a logit regression with all observations. Specification 2 includes only households and specification 3 includes only nonfinancial corporations. Specification 4 includes observations for which the realized capital gains for the fiscal year are known. There are no observations from year 1995 in specification 4. $t$-values are reported under coefficient estimates. Asterisks mark significance at standard levels $(* * *$ for $1 \%, * *$ for $5 \%$, and $*$ for $10 \%$, respectively).

\begin{tabular}{|c|c|c|c|c|c|}
\hline \multicolumn{2}{|l|}{ Dependent variable } & \multirow{2}{*}{\multicolumn{4}{|c|}{$\begin{array}{l}\text { Binary: } 1 \text { if investor arbitrages a stock going ex-dividend } \\
\text { Logit }\end{array}$}} \\
\hline \multirow{3}{*}{ Specification } & \multirow{3}{*}{$\begin{array}{l}\text { Expected } \\
\text { sign }\end{array}$} & & & & \\
\hline & & All & Household & $\begin{array}{c}\text { Nonfinancial } \\
\text { corporation }\end{array}$ & $\begin{array}{l}\text { Capital gains } \\
\text { available }\end{array}$ \\
\hline & & 1 & 2 & 3 & 4 \\
\hline Constant & $+/-$ & $\begin{array}{c}3.50 * * * \\
16.89\end{array}$ & $\begin{array}{l}3.70 * * * \\
12.63\end{array}$ & $\begin{array}{l}3.53 * * * \\
10.79\end{array}$ & $\begin{array}{l}4.62 * * * \\
9.56\end{array}$ \\
\hline Nonfinancial corporation & $+/-$ & $\begin{array}{l}0.22 * * * \\
2.99\end{array}$ & & & $\begin{array}{c}0.38 * * \\
2.24\end{array}$ \\
\hline Ln (portfolio value) & + & $\begin{array}{c}0.06 * * * \\
6.21\end{array}$ & $\begin{array}{l}0.07 * * * \\
4.70\end{array}$ & $\begin{array}{l}0.05^{* * * *} \\
3.25\end{array}$ & $\begin{array}{l}0.08 * * * \\
3.39\end{array}$ \\
\hline Weight in target stock & - & $\begin{array}{l}-1.05 * * * \\
-4.98\end{array}$ & $\begin{array}{l}-1.86^{* * *} \\
-6.19\end{array}$ & $\begin{array}{l}-0.08 \\
-0.27\end{array}$ & $\begin{array}{l}-1.71 * * * \\
-3.10\end{array}$ \\
\hline Capital gains & + & & & & $\begin{array}{l}-0.05 \\
-0.21\end{array}$ \\
\hline Ln (number of trades) & - & $\begin{array}{c}-0.93 * * * \\
-42.80\end{array}$ & $\begin{array}{c}-1.01 * * * \\
-31.25\end{array}$ & $\begin{array}{c}-0.84 * * * \\
-27.53\end{array}$ & $\begin{array}{c}-1.30 * * * \\
-18.52\end{array}$ \\
\hline Dividend yield & + & $\begin{array}{l}3.97 * * * \\
12.56\end{array}$ & $\begin{array}{l}4.00 * * * \\
9.94\end{array}$ & $\begin{array}{l}3.80^{* * * *} \\
7.08\end{array}$ & $\begin{array}{l}7.82 * * * \\
7.16\end{array}$ \\
\hline Bid/ask spread & - & $\begin{array}{c}-20.66^{* * *} \\
-6.16\end{array}$ & $\begin{array}{c}-28.37 * * * \\
-5.94\end{array}$ & $\begin{array}{c}-10.39 * * \\
-2.22\end{array}$ & $\begin{array}{c}-16.69 * * \\
-2.56\end{array}$ \\
\hline Beta & - & $\begin{array}{l}-0.56 * * * \\
-5.53\end{array}$ & $\begin{array}{c}-0.55 * * * \\
-4.11\end{array}$ & $\begin{array}{c}-0.58 * * * \\
-3.51\end{array}$ & $\begin{array}{c}-0.65 * * * \\
-2.91\end{array}$ \\
\hline Idiosyncratic risk & - & $\begin{array}{c}-0.94 * * * \\
-9.87\end{array}$ & $\begin{array}{l}-1.03 * * * \\
-8.42\end{array}$ & $\begin{array}{l}-0.79 * * * \\
-5.08\end{array}$ & $\begin{array}{c}-0.83 * * * \\
-4.28\end{array}$ \\
\hline $\begin{array}{l}\text { Standard deviation of } \\
\text { market index }\end{array}$ & - & $-61.51 * * *$ & $-45.76 * * *$ & $-86.56 * * *$ & $-78.20 * * *$ \\
\hline Year dummies & & -8.13 & -4.66 & -6.77 & -3.94 \\
\hline 1995 & & $\begin{array}{c}-2.84 * * * \\
-4.84\end{array}$ & $\begin{array}{l}-2.19 * * \\
-2.15\end{array}$ & $\begin{array}{c}-3.14 * * * \\
-4.37\end{array}$ & \\
\hline 1996 & & $\begin{array}{l}-0.03 \\
-0.22\end{array}$ & $\begin{array}{l}-0.16 \\
-0.69\end{array}$ & $\begin{array}{l}-0.20 \\
-1.16\end{array}$ & $\begin{array}{l}-0.11 \\
-0.34\end{array}$ \\
\hline
\end{tabular}


Table 7 -Continued

1997

1998

1999

2000

2001

Individual investor

characteristics

Female

Age - 15

Age 16-25

Age 26-35

Age 46-55

Age 56-65

Age 66 -

McFadden's pseudo $R^{2}$

Chi-square statistic

Number of observations

-0.08
-0.63
0.09
0.72
$-0.22 *$
-1.80
$0.33 * * *$
3.03
-0.09
-0.87

$-0.71 * * *$

$-0.01$

$-0.10$

$0.34 * *$

2.46

$-0.14$

$-1.05$

0.04

0.23

$-0.48$

$\begin{array}{ll}-0.04 & 0.04\end{array}$

$-0.24 \quad 0.16$

$-0.65^{* * *}$

$-0.28$

$-2.93 \quad-0.92$

$0.09 \quad 0.32$

$0.43 \quad 1.05$

$-0.17 \quad-0.34$

$\begin{array}{ll}-0.87 & -1.27\end{array}$
0.00

0.60

$0.78 * *$

2.54

$0.40^{*}$

1.89

0.09

0.74

$-0.08$

$-0.64$

$-0.04$

$-0.29$

0.05

0.26

$\begin{array}{cccc}0.355 & 0.383 & 0.292 & 0.509 \\ 4299.08 & 2665.66 & 1411.71 & 1246.42 \\ 30,492 & 12,941 & 17,551 & 2,561\end{array}$

\subsection{Determinants of ex-dividend day trading behavior}

A great deal of the theoretical work in the ex-day literature concentrates on the firm level determinants of tax arbitrage activity, but some authors such as Heath and Jarrow (1988), Michaely and Vila (1995), and Michaely, Vila, and Wang (1996) argue that individual investor factors other than differential tax rates are also relevant. I document here what determines the choice of stock for ex-dividend day trading.

I model the choice of tax arbitrage stock by using logit regression and coding overnight tax arbitrage trades as ones and control group overnight trades as zeros. The results are reported in Table 7, where I first pool all observations, and then segment the sample to study domestic household investors and nonfinancial corporations separately. As predicted by Kalay (1982) and consistent with the empirical findings of Karpoff and Walkling (1988), I find the propensity to engage in tax arbitrage to be positively related to dividend yield, and negatively related to 
transaction costs. The hypothesis that higher risk deters ex-dividend day traders (Michaely and Vila, 1995; Michaely et al., 1996) also gains strong support in the data.

Volatility of the market, beta risk, and idiosyncratic risk all diminish the probability that an investor will engage in overnight tax arbitrage. ${ }^{9}$ Consistent with Michaely et al. (1996), the results in all specifications indicate that idiosyncratic risk more strongly discourages trading than beta risk. There is also evidence that current holdings lessen the propensity to trade a stock around the ex-dividend day, which further supports the argument by Michaely and Vila (1995, p. 178) that idiosyncratic risk is a determinant of arbitrage activity.

The effect of total portfolio value is positive for the full sample and the subsamples of domestic households and nonfinancial corporations. Wealthier and more sophisticated investors execute relatively more overnight ex-dividend day trades. Age dummies exhibit almost a monotonic pattern; young investors tend to be financially savvier and trade more around the exdividend day. Sex has no significant impact on the probability an investor will engage in tax arbitrage.

Nonfinancial corporate investors trade relatively more around the ex-day than domestic households. There is also evidence that they are less risk-averse. The results for beta and idiosyncratic risk as well as for current holdings are stronger for households than for corporations.

The last column in Table 7 reports the results from a regression that includes a variable for capital gains. An investor with large realized capital gains would be expected to have more of an incentive to generate tax deductible losses by ex-dividend day trading than an investor with no or negative realized capital gains. The coefficient of the capital gains variable is negative, but not statistically significant at conventional levels.

These results explain which stocks investors trade around the ex-dividend day. Another way to look at the problem is to study which firms attract the most tax arbitrage activity as a fraction of the total trading volume. This requires an analysis from the firm level perspective, which is what I do next.

\footnotetext{
${ }^{9}$ Using risk measures estimated from the national market index assumes that international capital markets are fully segmented. As a robustness check, I rerun all analyses by using MSCI world total return index as the market portfolio. The results are not sensitive to the change in market index.
} 
Table 8

Firm level regressions on volume of tax arbitrage

This table documents results for the degree of tax arbitrage activity as a fraction of total trading volume. The dependent variable is binary in specifications 1 and 4 taking the value of 1 if there is any overnight tax arbitrage in a stock by domestic corporations and individuals around the ex-dividend day, zero otherwise. Specification 2 reports results from the second step of Heckman (1979) two-step estimation procedure. In specification 3 and in the second stage of specification 2, the dependent variable is continuous, defined as last cum-dividend day overnight tax arbitrage trading volume divided by the total trading volume on last cum-dividend day. In specification 4, all observations are grouped to 25 groups according to their dividend yield and bid/ask spread with a dummy for each group except for one. Ln (assets) is the natural logarithm of the total assets from the last reported fiscal year. All other variables are specified as in Table 7. $t$-values are reported under coefficient estimates. Specification 3 standard errors are computed by using the White (1980) procedure. Asterisks mark significance at standard levels $(* * *$ for $1 \%$, ** for $5 \%$, and $*$ for $10 \%$, respectively).

\begin{tabular}{|c|c|c|c|c|c|}
\hline \multicolumn{2}{|l|}{ Dependent variable: } & \multicolumn{4}{|c|}{ Tax arbitrage activity on cum-dividend day } \\
\hline \multirow[b]{2}{*}{ Specification } & \multirow[b]{2}{*}{$\begin{array}{l}\text { Expected } \\
\text { sign }\end{array}$} & \multicolumn{3}{|c|}{$\begin{array}{l}\text { Bid/ask and dividend yield as continuous } \\
\text { explanatory variables }\end{array}$} & \multirow{2}{*}{$\begin{array}{c}\text { Bid/ask and } \\
\text { dividend yield } \\
\text { quintiles as } \\
\text { dummies }\end{array}$} \\
\hline & & Probit & Heckman & OLS & \\
\hline & & 1 & 2 & 3 & 4 \\
\hline Constant & $+/-$ & $\begin{array}{l}-1.55 * * * \\
-3.83\end{array}$ & $\begin{array}{c}0.33 * * * \\
2.82\end{array}$ & $\begin{array}{l}0.19 * * * \\
3.02\end{array}$ & $\begin{array}{l}-0.83^{*} \\
-1.69\end{array}$ \\
\hline Bid/ask spread & - & $\begin{array}{l}-17.63 * * * \\
-5.87\end{array}$ & $\begin{array}{l}2.05 \\
1.16\end{array}$ & $\begin{array}{l}-0.63 * \\
-1.67\end{array}$ & \\
\hline Dividend yield & + & $\begin{array}{c}3.70 * * \\
2.09\end{array}$ & $\begin{array}{l}0.53 \\
1.22\end{array}$ & $\begin{array}{c}0.41 * * \\
2.25\end{array}$ & \\
\hline Beta & - & $\begin{array}{l}0.42 * * \\
2.18\end{array}$ & $\begin{array}{l}-0.02 \\
-0.33\end{array}$ & $\begin{array}{l}-0.01 \\
-0.30\end{array}$ & $\begin{array}{l}0.41 * * \\
2.11\end{array}$ \\
\hline Idiosyncratic risk & - & $\begin{array}{l}-0.07 \\
-0.54\end{array}$ & $\begin{array}{l}-0.09 * * \\
-2.19\end{array}$ & $\begin{array}{c}-0.02 * * \\
-1.98\end{array}$ & $\begin{array}{l}0.00 \\
0.01\end{array}$ \\
\hline Ln (assets) & + & $\begin{array}{c}0.20 * * * \\
4.80\end{array}$ & & $\begin{array}{l}0.00 \\
0.59\end{array}$ & $\begin{array}{c}0.21 * * * \\
4.81\end{array}$ \\
\hline $\begin{array}{l}\text { Standard deviation of } \\
\text { market index }\end{array}$ & - & $\begin{array}{c}24.72 \\
0.97\end{array}$ & $\begin{array}{l}-12.42 * \\
-1.65\end{array}$ & $\begin{array}{l}-6.41^{*} \\
-1.68\end{array}$ & $\begin{array}{c}20.31 \\
0.75\end{array}$ \\
\hline Year dummies & & & & & \\
\hline 1995 & & $\begin{array}{l}-0.04 \\
-0.06\end{array}$ & $\begin{array}{l}-0.08 \\
-0.41\end{array}$ & $\begin{array}{l}-0.09 * * \\
-2.47\end{array}$ & $\begin{array}{l}0.16 \\
0.21\end{array}$ \\
\hline 1996 & & $\begin{array}{c}0.48^{*} \\
1.87\end{array}$ & $\begin{array}{c}0.35^{* * *} \\
4.82\end{array}$ & $\begin{array}{c}0.25 * * * \\
4.45\end{array}$ & $\begin{array}{c}0.61 * * \\
2.16\end{array}$ \\
\hline 1997 & & $\begin{array}{c}0.53 * * \\
1.97\end{array}$ & $\begin{array}{c}0.34 * * * \\
4.64\end{array}$ & $\begin{array}{c}0.24 * * * \\
4.33\end{array}$ & $\begin{array}{c}0.83 * * * \\
2.79\end{array}$ \\
\hline 1998 & & $\begin{array}{l}0.21 \\
0.85\end{array}$ & $\begin{array}{c}0.26^{* * *} \\
3.73\end{array}$ & $\begin{array}{c}0.15^{* * *} \\
3.00\end{array}$ & $\begin{array}{l}0.41 \\
1.53\end{array}$ \\
\hline 1999 & & $\begin{array}{l}-0.26 \\
-1.08\end{array}$ & $\begin{array}{l}0.03 \\
0.38\end{array}$ & $\begin{array}{l}0.00 \\
0.09\end{array}$ & $\begin{array}{l}-0.23 \\
-0.88\end{array}$ \\
\hline 2000 & & $\begin{array}{l}-0.01 \\
-0.03\end{array}$ & $\begin{array}{l}0.09 \\
0.66\end{array}$ & $\begin{array}{l}0.06 \\
0.88\end{array}$ & $\begin{array}{l}0.22 \\
0.46\end{array}$ \\
\hline 2001 & & $\begin{array}{l}-0.33 \\
-0.97\end{array}$ & $\begin{array}{l}-0.02 \\
-0.15\end{array}$ & $\begin{array}{l}0.01 \\
0.15\end{array}$ & $\begin{array}{l}-0.16 \\
-0.45\end{array}$ \\
\hline Lambda & & & $\begin{array}{c}0.22 * * \\
2.22\end{array}$ & & \\
\hline
\end{tabular}


$\mathrm{D} / \mathrm{P}$ and Bid/ask quintile dummies

Pseudo $\mathrm{R}^{2}$

Adjusted $\mathrm{R}^{2}$

Chi-square statistic

F-statistic

Number of observations

\begin{tabular}{cccc} 
& & & Reported in Table \\
& & & 9 \\
0.235 & & & 0.288 \\
& & & \\
163.38 & 137.15 & 86.67 & 199.86 \\
501 & 11.14 & 7.55 & 501 \\
& 257 & 501 & \\
\hline
\end{tabular}

\subsection{Determinants of the degree of tax arbitrage activity}

I measure the degree of tax arbitrage activity by dividing the volume of tax arbitrage trades by domestic households and nonfinancial corporations by the total trading volume on the last cum-dividend day. In essence, this measure indicates what proportion of total trading volume is related to overnight tax arbitrage by domestic taxable investors. The variable has an average of $17.6 \%$, varies from zero to $100 \%$, and is nonzero in 257 of 501 cases.

A priori, there are strong grounds to expect that the degree of tax arbitrage activity is nonnormally distributed. This is because the expected ex-day price drop of firms that attract a nonzero degree of tax arbitrage activity should lie inside the no-arbitrage boundaries, which are determined by dividend yield and transaction costs. Similarly, there should also be many ex-day events with absolutely no arbitrage activity because arbitrageurs would not expect to make profits because of too high transaction costs and too low dividend yield. This theoretical requirement for a nonzero level of tax arbitrage activity creates a potential self-selection bias, which I correct by modeling the proportion of tax arbitrage activity using Heckman's (1979) sample selection specification. Ordinary least squares results are computed for comparison purposes.

I include a firm size variable in the first stage to control for the effect of thin trading - some of the smallest firms in my sample had zero trading volume on the last cum-dividend day. The variable is removed from the second stage of Heckit-estimation to ensure model identification.

The results, reported in Table 8, corroborate the findings from the investor level regressions. Transaction costs are negatively related and dividend yield and the size of the firm positively related to the probability that a firm attracts a strictly positive level of tax arbitrage activity. In the second stage, the degree of tax arbitrage activity is not driven by any of the first stage explanatory factors except for idiosyncratic risk.

In light of these results, one would say that the largest, most liquid, and the highest dividend yield firms attract the most tax arbitrage, but the variation in total volume (dependent variable denominator) dominates the variation in the volume of tax arbitrage activity (dependent variable 
numerator). The only unexpected result is the coefficient on beta in the first stage probitestimates, which is positive and significant at the $5 \%$ level.

In the last column of Table 8 , a nonlinear specification is introduced to model the interplay among dividend yield, transaction costs, and tax arbitrage activity. This specification is motivated by the functional form of no-arbitrage boundaries derived in Kalay (1982). The boundaries are determined by the quotient of dividend yield and proportional transaction costs rather than by their linear combination. I divide all observations into 25 groups according to dividend yield and bid/ask spread and assign a dummy for each group except for one.

Table 9 reports probit-regression coefficient estimates for all dummies and their respective $t$ values, which decline almost monotonically from the highest dividend yield/lowest bid-ask spread quintile to the lowest dividend yield/highest bid-ask spread quintile. This result is consistent with the argument that the joint effect of high dividend yield and low transaction costs rather than an extreme value in either of the variables alone is required to generate arbitrage activity. To demonstrate this effect further, I plot dummy variable coefficients in three dimensions in Figure 5.

Table 9

The effect of bid/ask spread and dividend yield on tax arbitrage

This table represents the coefficients of regression 4 in Table 8 . Lowest bid/ask and highest $\mathrm{D} / \mathrm{P}$ quintile is the reference level with no dummy. Asterisks mark significance at standard levels $(* * *$ for $1 \%$, $* *$ for $5 \%$, and $*$ for $10 \%$, respectively).

\begin{tabular}{|c|c|c|c|c|c|}
\hline \multicolumn{6}{|c|}{ Panel A: Coefficient estimates } \\
\hline \multirow[t]{2}{*}{$\mathrm{D} / \mathrm{P}$ quintile } & \multicolumn{5}{|c|}{ Bid/ask quintile } \\
\hline & 5 (Highest) & 4 & 3 & 2 & 1 (Lowest) \\
\hline 5 (Highest) & $-0.95^{*}$ & -0.59 & -0.66 & -0.30 & Omitted \\
\hline 4 & $-1.36 * * *$ & $-1.34 * * *$ & $-0.98 * *$ & $-1.07 * * *$ & -0.26 \\
\hline 3 & $-2.08 * * *$ & $-1.37 * * *$ & $-1.15 * * *$ & $-1.44 * * *$ & $-0.94 * *$ \\
\hline 2 & $-1.72 * * *$ & $-1.51 * * *$ & $-1.21 * *$ & $-1.59 * * *$ & $-1.25 * * *$ \\
\hline 1 (Lowest) & $-1.77 * * *$ & $-2.34 * * *$ & $-2.63 * * *$ & $-2.30 * * *$ & $-1.43 * * *$ \\
\hline \multicolumn{6}{|c|}{ Panel B: $t$-values } \\
\hline \multirow[t]{2}{*}{$\overline{\mathrm{D} / \mathrm{P} \text { quintile }}$} & \multicolumn{5}{|c|}{ Bid/ask quintile } \\
\hline & 5 (Highest) & 4 & 3 & 2 & 1 (Lowest) \\
\hline 5 (Highest) & -1.89 & -1.25 & -1.42 & -0.67 & Omitted \\
\hline 4 & -3.10 & -3.06 & -2.26 & -2.58 & -0.57 \\
\hline 3 & -4.37 & -2.94 & -2.60 & -3.45 & -2.35 \\
\hline 2 & -3.16 & -3.47 & -2.41 & -3.69 & -2.87 \\
\hline 1 (Lowest) & -3.22 & -4.93 & -4.46 & -4.87 & -3.25 \\
\hline
\end{tabular}




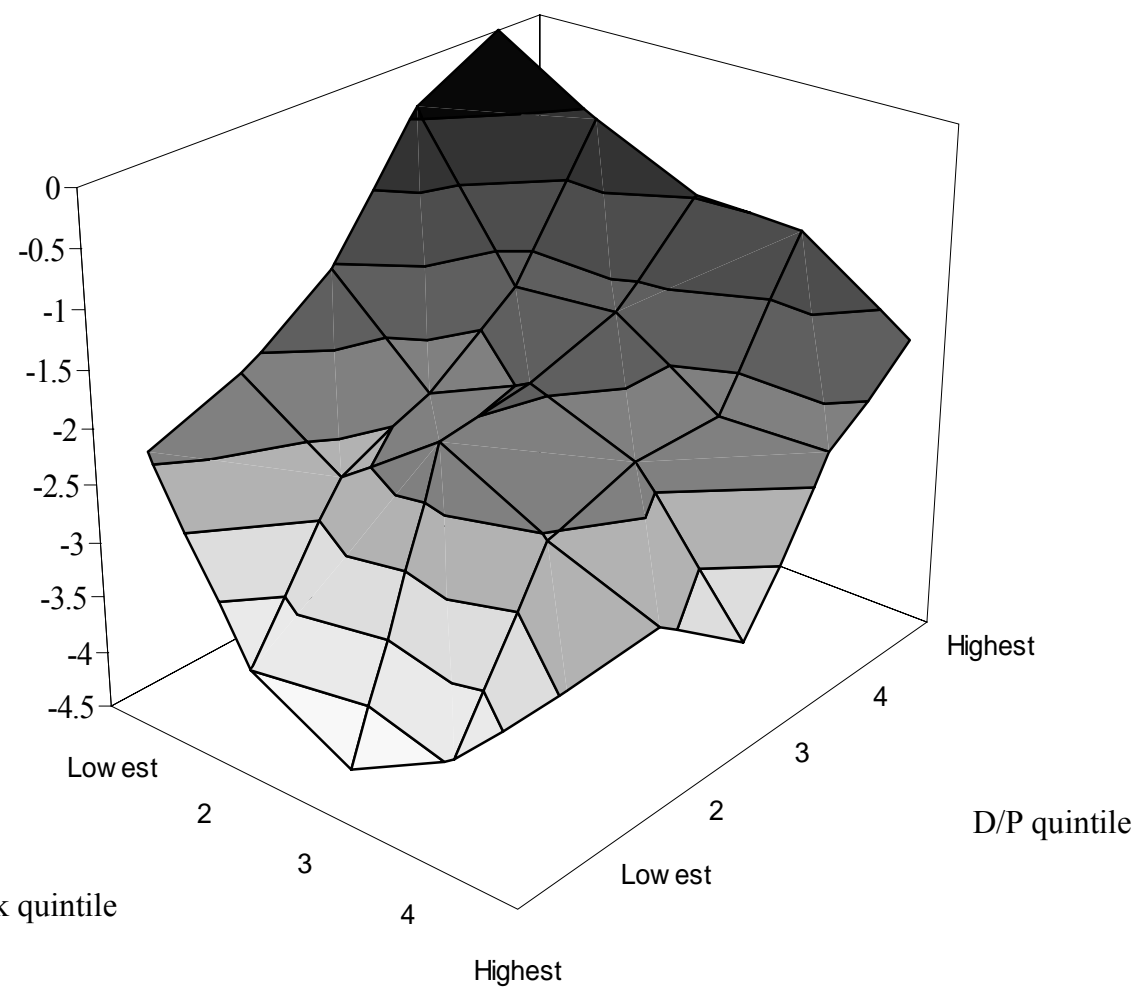

Fig. 5. Graphical representation of $\mathrm{D} / \mathrm{P}$ and bid/ask quintile coefficients. This figure plots the coefficient estimates for 24 dummy variables from regression specification 4 in Table 8 .

The firm level results are consistent with the investor level evidence, but reveal the dichotomous nature of the degree of arbitrage activity. Stocks with low transaction costs and high dividend yield attract tax arbitrage, but if the quotient of these variables is very low, there is no tax arbitrage at all.

\section{Conclusions}

I have documented which investors trade around the ex-dividend day and what determines their trading behavior. My findings support the interpretation that both differences in tax rates and arbitrage opportunities drive trading decisions around the ex-dividend day.

I show that domestic taxable investors engage in buy-sell tax arbitrage and that arbitrage by mutual funds generates positive profits. This is exactly what should happen in a market with differential tax rates on capital income and with no short-term capital loss deductibility restrictions. Although rising over time, the extent of ex-dividend day trading remains rather low. Thus, even in a country with few legal restrictions on ex-day trading, the majority of investors 
fail to understand the potential tax savings achievable by ex-day trading. This finding is consistent with earlier studies on individual trading decisions with respect to taxes. Evidence from the same market in Grinblatt and Keloharju $(2001,2004)$ as well as from the United States (Barber and Odean, 2003) indicates that although taxes matter in trading decisions, individual investors do not necessarily behave in a tax-optimal way.

Dynamic dividend clientele models do a fairly good job in predicting the trading behavior of household and nonfinancial corporate investors. In particular, idiosyncratic risk explains well what stocks investors trade. The relevance of idiosyncratic risk extends also beyond the ex-day literature. Whether idiosyncratic risk affects security prices is debatable (see, e.g., Bali, Cakici, and Yan, 2005), but my results suggest that at minimum it has an impact on investor trading decisions.

My analysis shows that several investor groups take advantage of the differences in tax rates by trading around the ex-dividend day. Although foreigners dominate the total trading volume, realized ex-day ratios would not suggest they are the marginal investors. In light of these results, a search for one group of marginal investors may be too restrictive, or even misleading.

So far, there is very little theory or empirical evidence on the interaction of various investor groups trading around the ex-day, although the work in Michaely and Vila (1995) is a step in this direction. A natural extension of this study would be an analysis of the interaction of different trading clienteles in the order book on the ex-dividend day. This could shed more light on which investors set the market price when investors have different preferences for pretax dividend income and capital gains. 


\section{References}

Allen, F., Michaely, R., 2004. Payout policy. In: Constantinides, G., Harris, M., Stulz, R., (Eds.), Handbook of economics. North Holland, Amsterdam.

Bali, T.G., Cakici, N., Yan, X.S., Zhang, Z., 2005. Does idiosyncratic risk really matter? Journal of Finance 50, 905-929.

Bali, R., Hite, G., 1998. Ex-dividend day stock price behavior: price discreteness or tax-induced clientele? Journal of Financial Economics 47, 127-159.

Barber, B.M., Odean, T., 2003. Are individual investors tax savvy? Evidence from retail and discount brokerage accounts. Journal of Public Economics 88, 419-442.

Bell, L., Jenkinson, T., 2002. New evidence of the impact of dividend taxation and on the identity of the marginal investor. Journal of Finance 57, 1321-1345.

Boyd, J., Jagannathan, R., 1994. Ex-dividend price behavior of common stocks. Review of Financial Studies 7, 711-741.

Callaghan, S., Barry, C.B., 2003. Tax-induced trading of equity securities: evidence from the ADR market. Journal of Finance 58, 1583-1612.

Dhaliwal, D.S., Li, O.Z., 2005. Investor tax heterogeneity and ex-dividend day trading volume. Journal of Finance, forthcoming.

Eades, K., Hess, P., Kim, H.E., 1984. On interpreting security returns during the ex-dividend period. Journal of Financial Economics 13, 3-34.

Elton, E., Gruber, M., 1970. Marginal stockholders' tax rates and the clientele effect. Review of Economics and Statistics 52, 68-74.

Felixson, K., Liljeblom, E., 2004. Evidence on ex-dividend day trading by investor tax-category. Unpublished working paper, Swedish School of Economics.

Frank, M., Jagannathan, R., 1998. Why do stock prices drop by less than the value of the dividend? Evidence from a country without taxes. Journal of Financial Economics 47, 161188.

Graham, J.R., 2003. Taxes and corporate finance: a review. Review of Financial Studies 16, $1074-1128$.

Graham, J.R., Kumar, A., 2005. Do dividend clienteles exist? Evidence on dividend preferences of retail investors. Journal of Finance, forthcoming.

Graham, J.R., Michaely, R., Roberts, M.R., 2003. Do price discreteness and transaction costs affect stock returns? Comparing ex-dividend pricing before and after decimalization. Journal of Finance 58, 2611-2635.

Green, R., Rydqvist, K., 1999. Ex-day behavior with dividend preference and limitation to shortterm arbitrage: the case of Swedish lottery bonds. Journal of Financial Economics 53, 145187.

Grinblatt, M., Keloharju, M., 2000. The investment behavior and performance of various investor types: a study of Finland's unique data set. Journal of Financial Economics 55, 43-67.

Grinblatt, M., Keloharju, M., 2001. What makes investors trade? Journal of Finance 56, 589-616.

Grinblatt, M., Keloharju, M., 2004. Tax-loss trading and wash sales. Journal of Financial Economics 71, 51-76. 
Heath, D.C, Jarrow, R.A., 1988. Ex-dividend stock price behavior and arbitrage opportunities. Journal of Business 61, 95-108.

Heckman, J.J., 1979. Sample selection bias as a specification error. Econometrica 47, 153-161.

Kalay, A., 1982. The ex-dividend day behavior of stock prices: a re-examination of the clientele effect. Journal of Finance 37, 1059-1070.

Karpoff, J.M., Walkling, R.A., 1988. Short-term trading around ex-days: additional evidence. Journal of Financial Economics 21, 291-298.

Kato, K., Loewenstein, U., 1995. The ex-dividend day behavior of stock prices: the case of Japan. Review of Financial Studies 8, 817-847.

Koski, J.L., Scruggs, J.T., 1998. Who trades around the ex-dividend day? Evidence from NYSE audit file data. Financial Management 27, 58-72.

Kukkonen, M., 2000. Capital gains taxation and realization behavior: evidence from Finnish panel data. Ph.D. dissertation, Helsinki School of Economics.

Lakonishok, J., Vermaelen, T., 1986. Tax-induced trading around ex-dividend dates. Journal of Financial Economics 16, 287-319.

Lasfer, M.A., 1995. Ex-day price behavior: tax or short-term trading effects. Journal of Finance $50,875-897$.

Liljeblom, E., Löflund, A., Hedvall, K., 2001. Foreign and domestic investors and tax induced ex-dividend day trading. Journal of Banking and Finance 25, 1687-1716.

MacDonald, R.L., 2001. Cross-border investing with tax arbitrage: the case of German dividend tax credits. Review of Financial Studies 14, 925-955.

Michaely, R., Vila, J-L., 1995. Investors' heterogeneity, prices, and volume around the exdividend day. Journal of Financial and Quantitative Analysis 30, 171-198.

Michaely, R., Vila, J-L., 1996. Trading volume with private valuations: evidence from the exdividend day. Review of Financial Studies 9, 471-510.

Michaely, R., Vila, J-L., Wang, J., 1996. A model of trading volume with tax-induced heterogeneous valuation and transaction costs. Journal of Financial Intermediation 5, 340371.

Naranjo, A., Nimalendran, M., Ryngaert, M., 2000. Time variation of ex-dividend day stock returns and corporate dividend capture: a re-examination. Journal of Finance 55, 2357-2372.

White, H., 1980. A heteroskedasticity consistent covariance matrix estimator and direct test for heteroskedasticity. Econometrica 48, 817-838. 